\title{
Carbonate production of an emergent reef platform, Warraber Island, Torres Strait, Australia
}

\author{
DEIRDRE E. HART ${ }^{1}$ (ग) \\ PAUL S. $\mathrm{KENCH}^{2}$ \\ ${ }^{1}$ Department of Geography, University of Canterbury, Private Bag 4800 \\ Christchurch 8020, New Zealand \\ deirdre.hart@canterbury.ac.nz \\ Phone +64 33792987 ext 7916 \\ Fax +64 33792907 \\ ${ }^{2}$ School of Geography and Environmental Science, University of Auckland, Private Bag 92019, \\ Auckland, New Zealand
}

\section{Abstract}

Complex relationships exist between tropical reef ecology, carbonate $\left(\mathrm{CaCO}_{3}\right)$ production and carbonate sinks. This paper investigates census-based techniques for determining the distribution and carbonate production of reef organisms on an emergent platform in central Torres Strait, Australia, and compares the contemporary bu dget with geological findings to infer shifts in reef productivity over the late Holocene. Results indicate that contemporary carbonate production varies by several orders of magnitude between and within the different reef-flat sub-environments depending on cover type and extent. Average estimated reef flat production was $1.66 \pm 1.78 \mathrm{~kg} \mathrm{~m}^{-2} \mathrm{yr}^{-1}$ (mean $\pm \mathrm{SD}$ ) although only $23 \%$ of the area was covered by carbonate producers. Collectively, these organisms produce 17,399 $\pm 18,618 \mathrm{t} \mathrm{CaCO}_{3} \mathrm{yr}^{-1}$, with production dominated by coral $(73 \%)$ and subordinate contributions by encru sting coralline algae (18\%) articulated coralline algae, molluscs, foraminifera and Halimeda $(<4 \%)$. Comparisons between these organisms production across the different reef flat zones, surface sediment composition and accumulation rates calculated from cores indicate that it is necessary to understand the spatial distribution, density and production of each major organism when considering the types and amounts of carbonate available for storage in the various reef carbonate sinks. These findings raise questions as to the reliability of using modal production rates in global models independent of ecosystem investigation, in particular, indicating that current models may overestimate reef productivity in emergent settings.

Key words calcification, carbonate production, reefflat, Torres Strait, coral, coralline algae, Halimeda, foraminifera, molluscs

\section{Introduction}

Carbonate production by coral reefs located throughout the tropical and sub-tropical oceans is an important component of the global carbon cycle (Vecsei 2004). Recent carbonate studies have focussed on estimating global values of reef production to support climate modelling (Milliman 1993; Kleypas et al. 1999; Vecsei 2004). Such global estimates are dependent on 
up-scaling from a small number of individual coral reef studies that represent limited coverage of the world's reefs.

At the reef platform scale carbonate production estimates are also of critical importance in understanding the geological and geomorphic development of coral reefs and islands. Production by primary frame builders (corals and encrusting coralline algae) is an important component in reef development (Hubbard et al. 1990). Furthermore, carbonate production by primary frame builders and secondary benthic organisms, along with mechanical and biological erosion, control the generation of detrital sediment on reef platforms, sediment which is subsequently: reincorporated in to reef framework (Hubbard et al. 1990); stored on reef surfaces; transported off-reef (Hughes 1999); or transferred to infill lagoons (Macintyre et al. 1987; Kench 1998; Purdy and Gischler 2005) or build islands (Maragos et al. 1973; Hopley 1982; Woodroffe et al. 1999; Yamano et al. 2000, 2002). To date few studies have attempted to quantify how fine spatial variations in organism density and production influence the character of both reef framework and sediment reservoirs. Notable exceptions include Stearn et al. (1977) and Scoffin et al. (1980) in Barbados; Sadd (1984) and Hubbard et al. (1990) in the Caribbean; and Harney and Fletcher (2003) in Hawaii. Collectively these papers highlight the limited geographical and physiographic coverage of such studies. All were conducted in non-emergent, fringing reef environments potentially influenced by highisland silicate or hydrological inputs so that their results have limited applicability in interpreting the emergent, carbonate environments of Great Barrier Reef (GBR) platforms and Pacific atolls.

Vecsei (2004) identifies four principal approaches used to quantify carbonate production on reefs: i) hydrochemical techniques based on water chemistry changes (Davies and Kinsey 1977; Smith and Harrison 1977; Smith and Kinsey 1976, 1978; Smith 1981, 1983; Kinsey 1985); ii) the census-based approach, which uses data on reef organism cover and extension/production rates (Chave et al. 1972; Stearn et al. 1977; Sadd 1984; Hubbard 1985; Vecsei 2001; Yamano et al. 2000; Harney and Fletcher 2003); iii) geological estimates from net accumulations of carbonate on individual reefs (Ryan et al. 2001); and iv) modelling techniques focussed on net reef accumulation (Kleypas 1997). All these approaches yield aggregate estimates of production at the total reef scale but only the first two, hydrochemical and census-based methods, are applicable at sub-reef scales or in evaluating organism-level production differences.

Productivity rates calculated from hydrochemical (alkalinity-reduction) measurements alone include both the carbonate precipitation and early dissolution occurring in shallow reef waters (Kinsey 1985). These measurements commonly represent carbonate production by entire reef communities and not the relative contributions of different producer types. The widespread adoption of hydrochemical methods over the last three decades has led to significant advances in understanding the productivity of different reef-habitat assemblages (Kinsey 1983; Milliman 1993; Vecsei 2004). These advances have, however, been at the expense of detailed knowled ge of the relative contributions of different organism types to gross reef production.

In contrast, census methods afford the opportunity to determine the relative contributions of different carbonate producers to total reef productivity as well as opportunities for detailed 
spatial comparisons between carbonate contributions and sediment composition, and between patterns of 'framework' versus 'direct-sediment' production (Harney and Fletcher 2003) at sub-reef scales. This study documents detailed pattern s of carbonate production on an emergent reef-flat as determined using census-based techniques.

Smith and Kinsey (1976) criticised census techniques for their potential for error from the accumulation of contributions by individual biological components. However, there have been sufficient, significant advances in the extent and accuracy of published carbonate producer growth rates to warrant reconsideration of the accuracy of census techniques, and a review of the rates that underlie them. Further, the robustness of census-based results may be easily tested via error estimates and comparisons drawn with hydrochemically-determined modal production rates.

This paper presents results from the application of census techniques to construct a high spatial and organism-type resolution budget of carbonate production (types, quantities and distribution) on the emergent reef flat of Warraber Reef, Torres Strait, Australia (10 $12^{\circ}$ S, $\left.142^{\circ} 49^{\prime} \mathrm{E}\right)$. Estimates of production are evaluated via error analyses and comparison s with published estimates from other reef environments. Results highlight the improved spatial resolution that the census approach provides in understanding how several types of reef organisms contribute differently to sediment and framework sinks in reef platform environments. The implications of such differences are explored with regard to the geological development of reef platforms, global carbon budgets, and the generation of detrital sediments. While production on the platform slope is likely to rival that produced on the reef top, this paper focuses on the latter environment since the Warraber reef flat is a relatively closed system in terms of carbonate and sediment generation.

\section{Materials and methods}

\section{Field setting}

Torres Strait consists of a shallow (15-25 m deep) shelf with scattered islands, reefs and shoals, situated between north-eastern Australia and southern Papua New Guinea (Fig. 1). Reefs grow throughout the Strait fringing high islands and as large platforms and coral shoals (Woodroffe et al. 2000).

Warraber (Sue) Reef comprises a small cay and large platform system, with a total area of 11 $\mathrm{km}^{2}$, situated in the central Strait. A planar-type reef (Hopley 1982), Warraber is flanked by two parallel, slightly-deeper (1-2 m) platforms, Burrar (Bet) and Guijar (Poll) Reefs, which together are referred to as the Three Sisters (Fig. 1b).

Warraber Island comprises a $750 \mathrm{~m}$ by $1,500 \mathrm{~m}$ wide, oval-shaped, low-elevation (2-8 $\mathrm{m}$ above mean sea level, MSL) cay fringed by sandy beaches and situated towards the northwestern corner of the reef platform (Fig. 1a). The island and surrounding reef flat are Holocene in origin, having formed over a shallow Pleis tocene platform (Woodroffe et al. 2000). The present reef flat comprises two distinct areas separated by differences in gross elevation but both fringed by an elevated, youthful coral-algal rim (Fig. 1c): a large, elevated, central platform in the east, with extensive sand flats covering fossil microatolls and 
branching coral; and smaller, lower, western reef flat, characterised by inner muddy sandflats and outer coral patches interspersed with sandy channels plus a boat channel, constructed in 1991, dividing the area in two. Woodroffe et al. (2000) interpret the western reef flat as more youthful than the central, emergent fossil reef flat.

\section{Climate and oceanographic regime}

Strong tidal currents (up to $4 \mathrm{~ms}^{-1}$ ) scour the bed of Torres Strait affecting the form of reef development and the area is subject to wind-generated surges developed locally, in the Indian Ocean, and in the Coral Sea (Amin 1978). Torres Strait lies north of the main cyclone belt of the GBR, with the central Strait having experienced seven Category 1-2 cyclones since 1910 (Puotinen 2004).

Warraber Reef experiences a semi-diurnal, meso-tidal regime with a maximum range of $4 \mathrm{~m}$ above the lowest astronomical tide (ALAT). The entire reef flat is submerged at high tide, at which time offshore wave energy propagates across the platform. Conversely, at lower stages of the tide, the elevated central area and reef rim are largely exposed while the outer reef flat experiences ponding (Brander et al. 2004). Significant wave heights outside the platform range from 0-1 m during the wet season, when north-westerly wind srevail, to 0-2 $\mathrm{m}$ during the dry season, when south-easterly winds prevail (Young and Holland 1996).

\section{Methodology}

Aerial photographs and initial field investigations were used to construct preliminary physiographic maps of the reef flat including a network of seven, 0.6-3.5 km long transects spaced around the island and radiating out to the reef edge. Transects were surveyed using a staff and level and, within sets of three $1 \mathrm{~m}^{2}$ quadrats at 37 sites along the transects, observations were made of sediment depth and type, and living organism type and planimetric cover or abundance (Appendix 1). Rugosity was gauged as the ratio between the length of chain required to cover the cross-sectional profile of a quadrat and the $1 \mathrm{~m}$ aerial width of the quadrat profile (with 1-4 indicating flat to very rugose surfaces respectively). Data from the transects were supplemented with additional quadrat surveys in each broad reef zone between them.

Coral species were identified using Veron $(1986,2000)$ and Wood (1983) and growth forms recorded. Molluscs were identified using Short and Potter (1987), Cernohorsky (1978), Hilton $(1978,1979)$ and Wilson and Gillett (1971) while foraminifera were identified using Jones (1994).

Analysis of variance (Single Factor ANOVA and Monte Carlo Randomisation Tests) was performed on the quadrat cover data for each organism type to compare inter- versus in trasite variation (Zar 1999). Cover types were mapped along RT1-RT7 and observations from intervening areas were used to classify the remaining reef flat. A map of ecological zones was constructed and the area occupied by each zone was calculated.

In this paper, the term 'calcification' refers to the potential carbonate production rates $\left(\mathrm{g} \mathrm{m}^{-2}\right.$ $\mathrm{yr}^{-1}$ ) of individual organisms, while 'production' or 'carbonate production' refers to the

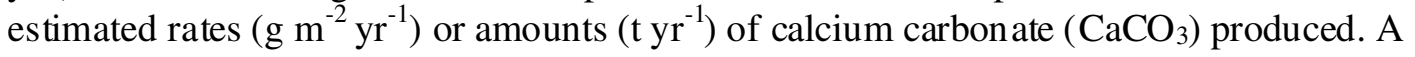


review of published figures was conducted to determine the calcification rates, skeletal densities and aerial adjustment factors to apply to carbonate-producing organisms found on the reef flat in order to calculate per-quadrat production rates (Appendix 1).

Calculated potential production rates for organisms found in each quadrat (average cover $>1 \%$ ) were then summed and results from replicate quadrats were averaged to give gross carbonate production estimates per site $\left(\mathrm{g} \mathrm{m}^{-2} \mathrm{yr}^{-1}\right)$. The quadrat data and calculated zonal areas were summed to produce gross carbonate production rates and standard deviations $(\sigma)$ $\left(\mathrm{g} \mathrm{m}^{-2} \mathrm{yr}^{-1}\right)$. Maximum, minimum and best-estimate carbon ate production figures were compared in order to test sensitivity to variation in species' production rates. This variation was then compared to that which resulted from the patchy nature of cover in survey quadrats (spatial variation).

\section{Results}

\section{Reef flat morphology}

Transects RT1 to RT6 show marked differences in reef flat width, elevation and topographic complexity around Warraber Island (Fig. 2). Reef flat width from island shore to reef rim ranges from $2,700 \mathrm{~m}$ to $600 \mathrm{~m}$ from east to west, with a $0.7-1 \mathrm{~m}$ difference in elevation between the elevated eastern (RT1-RT3) and lower western (RT4-RT6) transects. The broad eastern reef can be divided into three morphological components: an elevated inner-reef platform (0-1,000 $\mathrm{m}$ from shore, predominantly above MSL) that reflects higher reef growth during the mid-Holocene; a central basin (1,000-2,200 $\mathrm{m}$ from shore, predominantly below MSL); and a higher-elevation windward reef rim (2,200-2,700 $\mathrm{m}$ from shore, situated AMSL). In contrast, the narrower, deeper, western reef flats do not exhibit distinct morphological differences but rather possess more-varied local-scale topography, reflecting the presence of muddy sandflats versus large live microatolls, interspersed by sandy hollows and dense, branching-coral thickets.

\section{Spatial variability in living cover}

The live cover data from quadrats along RT1-RT5 were analysed for spatial variability (Table 1): analysis of variance tests (Single Factor ANOVA and Monte Carlo Randomisation) indicate that for all cover types, except coral-massive and coral-fol/encr/mu, data from the three replicate quadrats at each site were more similar than any random combination of quadrats $(\mathrm{P}<0.05)($ Table 1a-b). The non-significance of results for coral-massive $(\mathrm{P}>0.1)$ and coral-fol/encr/mu $(\mathrm{P}>0.4)$ reflects the highly-variable local distribution patterns of these cover types. For example, massive corals commonly covered $80-100 \%$ of quadrats they occupied, but $0 \%$ of adjacent replicate quadrats, which frequently contained $100 \%$ sandy substrate. Alone neither type of quadrat accurately represents local ecological cover but in combination they indicate the types and densities of organisms present. It was, thus, deemed suitable to group cover data from each set of three replicate quadrats into averaged 'per site' values.

Inter-transect variation was not greater than intra-transect variation (Table 1c) with P-values significant $(<0.05)$ only for the category 'coral-ramose-other', indicating that $v$ ariation 
between sites across the reef flat as a whole was no greater than the variation found along each transect for all other cover types. Accordingly, it was deemed inappropriate to further group the cover data by transect. This find ing indicates a pattern of ecological zones running across, rather than along, the reef transects. For the cover type 'coral-ramose-other' the higher inter-transect variation is consistent with the division of the reef flat in to a series of elevated eastern and lower western zones, the latter of which is based primarily on variation in the cover of Montipora digitata. West of the boat channel M. digitata is sparse, occurring in outer reef flat zones as small to medium sized branching colonies while east of the boat channel $M$. digitata forms a number of tall, wide, dense, monospecific bands mid-way across the reef flat which are replaced by a moderately-tall, dense, mixed cover of $M$. digitata and Acropora species and massive coral colonies.

Based on the 'per site' census data and observations from intervening areas, ten ecological reef flat zones were determined according to percentage living cover and substrate type, each zone being characterised by a distinct combination of biological assemblages and substrate types (Fig. 3). All of the eastern zones were $>1 \mathrm{~km}^{2}$, with those in the west and north $<0.5$ $\mathrm{km}^{2}$ each, while the total area covered by the zones (i.e. excluding the boat channel and island) was $10.46 \mathrm{~km}^{2}$. The island, boat channel and whole reef platform cover $0.81 \mathrm{~km}^{2}$, $0.06 \mathrm{~km}^{2}$ and $11.33 \mathrm{~km}^{2}$ respectively (Fig. 3).

\section{Reef flat carbonate productivity}

Table 2 summarises the organism-level calcification rates used to calculate carbonate production on the Warraber reef flat. The results of these calculations are summarised for each zone in Table $3 \mathrm{a}$, which shows the 'best estimate' carbon ate production rates $\left(\mathrm{g} \mathrm{m}^{-2} \mathrm{yr}^{-1}\right)$ of the different assemblages of organisms with standard deviations indicating levels of interquadrat variation in each zone.

Productivity estimates vary between the ten zones by two orders of magnitude, from $65 \mathrm{~g} \mathrm{~m}^{-2}$ $\mathrm{yr}^{-1}$ in Zone 5 to $3,999 \mathrm{~g} \mathrm{~m}^{-2} \mathrm{yr}^{-1}$ in Zone 6 . Such large differences are expected and are due to spatial variability in live cover and the composition of carbonate-producing assemblages found in each zone (e.g., mollusc versus coral dominated). The most productive areas (1,764$\left.3,999 \mathrm{~g} \mathrm{~m}^{-2} \mathrm{yr}^{-1}\right)$ are located on the cen tral to outer reef flat zones characterised by massive and mixed-branching/massive coral cover (Zones 3,6,9), while moderate amounts of carbonate (566-1,081 $\left.\mathrm{g} \mathrm{m}^{-2} \mathrm{yr}^{-1}\right)$ are produced in the dense-branching and reef-rim zones (4, $7 \mathrm{a}-7 \mathrm{~b})$. The least productive areas of the reef flat $\left(65-161 \mathrm{~g} \mathrm{~m}^{-2} \mathrm{yr}^{-1}\right)$ are those dominated by sandy or muddy substrate located close to the island and on the elevated eastern reef flat (Zones 1-2, 5, Table 3a).

In addition to between-zone differences in estimated carbonate production rates, a large degree of within-zone variation was found as demonstrated by the standard deviations associated with each rate (Table 3a). This variation is explained by the patchy nature of the ecosystems. In Zone 3, for example, quadrats with $100 \%$ cover of highly-productive massive and branching corals occurred adjacent to quadrats containing only bare sand. Analysis of variance performed on the per quadrat carbonate-production data (One-way ANOVA and Monte Carlo Randomisation Tests) conf irm that, despite the high degree of intra-zonal variation, the zonal grouping of quadrats is highly significant $(\mathrm{P}<0.001$, degrees of freedom between groups $=9$ and within groups $=101, \mathrm{n}=111$ ). 


\section{Total reef flat carbonate production}

The average rate of estimated carbonate production for the reef flat as a whole was $1,663 \pm$ $1,780 \mathrm{~g} \mathrm{~m}^{-2} \mathrm{yr}^{-1}$ (mean $\pm \mathrm{SD}$ ) (Table 3a) with the total area covered by carbonate-producing organisms $2.41 \mathrm{~km}^{2}$ or $23 \%$ of the total reef flat. These organisms produce an estimated $17,399 \pm 18,618 \mathrm{t} \mathrm{CaCO}_{3} \mathrm{yr}^{-1}$ (mean $\pm \mathrm{SD}$ ) (Table 3b). Total production varies by three orders of magnitude between zones, from $30 \mathrm{t} \mathrm{yr}^{-1}$ in Zone 5 to $12,575 \mathrm{t} \mathrm{yr}^{-1}$ in Zone 3, as a function of the area of each zone, as well as of the calcification and cover rates of organisms present.

Table $3 \mathrm{~b}$ presents estimates of the amount of carbonate contributed annually by the different producer types, highlighting spatial variability in the importance of carbonate producing organisms on the reef surface. Production was dominated by molluscs in Zones 1-2, by coral in Zones 3, 6, 8 and 9 and by encrusting coralline algae in Zones 4 and 7b. Despite the importance of each of these organisms within individual zones, some are quantitatively of little importance to total production. The dominance of coral in Zone 3, for example, represents far more carbonate $\left(11,120 \mathrm{t} \mathrm{yr}^{-1}\right)$ than the dominance of molluscs in Zones 1-2 (100-193 $\left.\mathrm{t} \mathrm{yr}^{-1}\right)$. Total production on the Warraber reef flat is dominated by Zone 3 (70\% of total or $12,575 \mathrm{t} \mathrm{yr}^{-1}$ ) while the majority $(87 \%)$ of carbonate produced on the reef flat is contributed by only three producers: massive corals (59\%), encrusting coralline algae (18\%), and branching Acropora (10\%). Other producers contribute $\leq 4 \%$ each to total carbonate production (Table $3 b$ ).

Comparison s between the percentage of total carbonate produced by each type of organism and $\operatorname{cover}^{\mathrm{b}}$ (the cover an organ ism relative to the total area occupied by carbonate producing organisms, $2.41 \mathrm{~km}^{2}$ ) reveals a markedly non-linear relationship (Table 3) due to the differential growth and production rates in Table 2 . Most notably production by massive, branching-Acropora and fol/encr/mu corals is large relative to their areal cover, whilst production by encrusting coralline algae, other branching corals, Halimeda and articulated coralline algae is small relative to their cover. Further, the dominant carbonate producer at each site was rarely the dominant cover type. This is due to the predominance of the noncarbonate producing brown algae as well as to the large amount of carbonate produced by corals per unit area compared to encrusting coralline algae.

\section{Sensitivity of production results to growth rates}

The sensitivity of carbonate production results to variations in organism growth rates was modelled for the main carbonate producers using mean (best-estimate), minimum and maximum calcification rates (Table 2) which, as indicated in Appendix 1, are conservative and excessive production values respectively. By comparison with the mean scenario, the proportion of carbonate produced by individual organism types changes by $<4 \%$ and $<2 \%$ under the minimum and maximum scenarios respectively (Table 4) with estimated total carbonate produced under these scenarios 7,726 and 26,347 $\mathrm{t} \mathrm{yr}^{-1}$ respectively, corresponding to average production rates of 738 to $2,518 \mathrm{~g} \mathrm{~m}^{-2} \mathrm{yr}^{-1}$.

Such comparisons do not indicate the effect of each organism experiencing different growth conditions, some finding them average, others optimal or suboptimal. Under these circumstances greater variation in the proportion of carbonate produced by each organism 
could be expected, with total production somewhere between 7,726 and $26,347 \mathrm{t} \mathrm{yr}^{-1}$. Using the maximum coral scenario but minimum scenario for other organisms, the proportion of carbonate produced by coral would increase $14 \%$, while decreasing $8 \%$ for coralline algae and $0-4 \%$ for other organisms. Total production under this scenario is $12,763 \mathrm{t} \mathrm{yr}^{-1}$.

Potential variation in carbonate production with differing growth conditions may be contextualised relative to actual variation resulting from the patchy nature of reef ecosystems (adjacent quadrat cover variation) as indicated by standard deviations in Table 3. Spatial variation in the best-estimate carbonate production on Warraber (i.e. \pm SD) is of the order of $\pm 18,618 \mathrm{t} \mathrm{yr}^{-1}( \pm 107 \%)$, or $\pm 1,780 \mathrm{~g} \mathrm{~m}^{-2} \mathrm{yr}^{-1}$. Thus the potential variation in carbonate production resulting from the patchy nature of reef ecosystems is greater than that which might result from variable growth conditions.

\section{Discussion}

The census approach yields estimates of carbonate production by organism-type at a number of spatial scales, including the entire reef platform, eco-morphological zones on a reef platform, and within eco-morphological zones. Of interest are: how these results compare with carbonate rates calculated for reef platforms elsewhere; how the census approach compares with commonly-used alkalinity reduction and geological techniques; whether the census approach provides improved accuracy and resolution of carbonate productivity on reefs and; implications for in terpreting reef-flat carbonate productivity, geological development of reef platforms and sediment budgets.

\section{Warraber carbonate productivity in global context}

Table 5 contain s examples of published gross carbonate-production estimates alongside those calculated for Warraber (for a comprehensive review of carbonate-production rates up to 1985 see Kinsey 1985). The estimates of Smith and Kinsey (1976) and Kinsey (1981) are given as examples of rates calcu lated using alkalinity-reduction techniques which, as noted, include both carbonate precipitation and early dissolution. In recognition of methodological differences, comparisons focus on the order of magnitude of estimates. The average estimated production rate for the Warraber reef flat, $1.66 \mathrm{~kg} \mathrm{~m}^{-2} \mathrm{yr}^{-1}$, is lower than the majority of estimates from other reef environments, which range between $0.8-30.5 \mathrm{~kg} \mathrm{~m}^{-2} \mathrm{yr}^{-1}$. The Warraber rate is, however, of the same order of magnitude as those from other reef-flat studies (c. $4 \mathrm{~kg} \mathrm{~m}^{-2} \mathrm{yr}^{-1}$, Table 5).

A number of factors could contribute to the low production value for Warraber and reef flats in general. First, Warraber is an emergent reef flat where productivity is constrained across broad tracts of elevated reef. Second, it is important to note that Table 5 lists studies undertaken in different reef environments and where production was dominated by different organisms. On the Warraber reef flat, the total estimated carbonate production was dominated by coral $(74 \%)$, with subordinate proportions produced by encrusting coralline algae (18\%) and other organisms in minor proportions (Table $3 b$ ).

In reef flat environments, low production rates have also been reported by Yamano et al. (2000) on a coral, Halimeda and foraminifera dominated reef surface and by Eakin (1996) with production dominated by coralline algae (56\%) and coral (44\%). A few studies of other 
environments have found similar low productivity values: for example, Stearn et al (1977) on Bellairs fore-reef slope where coral was responsible for $71 \%$, and coralline algae for $29 \%$, of production, and Hubbard et al. (1990) on a shelf-edge reef where coral comprised 93\%, and coralline algae $7 \%$, of production.

\section{Comparison of census-based and alkalinity-reduction techniques}

From an extensive review of alkalinity-reduction studies, Kinsey $(1983 ; 1985)$ proposed that a series of absolute carbonate production rates were applicable to reefs in the latitudinal range $23^{\circ} \mathrm{S}$ to $23^{\circ} \mathrm{N}: 4 \mathrm{~kg} \mathrm{~m}^{-2} \mathrm{yr}^{-1}$ on high-energy Pacific coral/algal reef-flat and rim environments; $0.5 \mathrm{~kg} \mathrm{~m}^{-2} \mathrm{yr}^{-1}$ in sheltered sandy back-reef environments; and $2 \mathrm{~kg} \mathrm{~m}^{-2} \mathrm{yr}^{-1}$ in shallow coral environments.

For comparison with the census approach used here the Kinsey modes were applied to Warraber, with Zones 1, 2 and 5 classified as sandy back-reef; Zones 4, 7a and 7b as highactivity rim; and Zones 8 and 9 as shallow-coral environments. Due to the patchy nature of coral and sand cover in Zones 3 and 6 these were characterised as intermediate between Kinsey's sandy reef-flat and shallow-coral environments. Using these modes, total annual carbonate production for the entire reef flat is $16,540 \mathrm{t} \mathrm{yr}^{-1}$, with an average production rate of $1.58 \mathrm{~kg} \mathrm{~m}^{-2} \mathrm{yr}^{-1}$. At the level of the entire reef flat these results compare well with the censusbased estimates, providing a first approximation of reef flat carbonate productivity.

Important differences exist, however, at the ind ividual reef-zone scale. Fig. 4a-b compares the census results with those calculated using Kinsey's modes across each zone: major differences occur in zones characterised as reef rim (4,7a and $7 b)$ or sandy reef flat with patchy mixed coral cover ( 3 and 6). Zones 3 and 4, for example, contribute $24 \%$ and $52 \%$ of total carbonate produced when calculated using Kinsey's modes versus census-based estimates of $72 \%$ and $13 \%$. These comparisons highlight the need for more-than-superficial classification of reef ecosystems when using alkalinity-reduction based modes to estimate carbonate productivity and raise questions of accuracy regarding their application in global models of reef productivity independent of ecosystem investigation.

Fig. 4a also differentiates the carbonate produced across the reef flat by 'framework' versus 'direct sediment' producers (after Harney and Fletcher 2003), a distinction not possible with alkalinity-reduction results. Direct sediment production is shown to comprise a minor proportion of total carbonate production on the reef flat $(8 \%)$.

In addition to the above inter-zone insights, the census-based approach provides improved resolution of spatial variations in productivity within individual reef-flat zones. As outlined in Appendix 1, with the exception of molluscs, the contemporary growth rates of carbonateproducing organisms are well documented from a number of reefs and reef environments and show that growth rates vary according to environmental conditions and the age and health or organisms.

However, Scoffin and Garrett (1974) and Vecsei $(2001,2004)$ show that growth rates are sufficiently similar with in species for slight variations in the cover of one species relative to another to drastically alter the constituent composition of carbonate sinks. Both the rates expressed in Table 2, and the comparisons made between productivity variations due to the 
patchy nature of reef ecosystems and potential variation in growth conditions support this assertion. The potential for variation in carbonate sinks due to variation in species cover rates is ultimately expressed in the estimates summarised in Table 3, which show that productivity varies considerably between the different zones or sub-environments of the reef flat (0.065$3.99 \mathrm{~kg} \mathrm{~m}^{-2} \mathrm{yr}^{-1}$ ) depending on the cover of different producers.

For example, these figures are particularly sensitive to the presence of massive coral, which is highly-productive and largely limited to the deeper, central to outer reef flat (Zones 3, 6, 9). Within these zones estimated production rates $\left(1.76-3.99 \mathrm{~kg} \mathrm{~m}^{-2} \mathrm{yr}^{-1}\right)$ approach average rates published for other reef flats (Table 5). In contrast, estimated production rates for the moderately-productive, monospecific branching-coral Zone 8 and raised coralgal-rim Zones $4,7 \mathrm{a}$ and $7 \mathrm{~b}\left(0.57-1.08 \mathrm{~kg} \mathrm{~m}^{-2} \mathrm{yr}^{-1}\right)$ are comparable to those recorded for sand areas (0.4-1.2 $\left.\mathrm{kg} \mathrm{m}^{-2} \mathrm{yr}^{-1}\right)$ in Kinsey (1985). Estimates from the least-productive, sandy, inner reef-flat zones on Warraber $\left(0.065-0.15 \mathrm{~kg} \mathrm{~m}^{-2} \mathrm{yr}^{-1}\right)$ are amongst the lowest-recorded carbonate production rates.

\section{Geological context of the census-based findings}

The spatial variations (intra-reef-flat) in carbonate production highlighted by the censusbased estimates provide a basis for evaluating long-term changes in reef production from the mid-late Holocene at the sub-reef scale. Gross vertical framework accretion on Warraber may be estimated using average carbonate production rates for each type of framework builder (corals, encrusting coralline algae) present in a zone divided by their individual densities (listed in Appendix 1). This gives a gross vertical framework accretion rate for the reef flat as a whole of $1.15 \mathrm{~mm} \mathrm{yr}^{-1}$, with rates varying from 2.25 to $6.34 \mathrm{~mm} \mathrm{yr}^{-1}$ on the outer reef flat, from 0.35 to $0.56 \mathrm{~mm} \mathrm{yr}^{-1}$ on the reef rim, and at $0.0 \mathrm{~mm} \mathrm{yr}^{-1}$ on the inner reef flat (Fig. 4c). Accumulation rates vary across the ten ecological zones, independent of zone size, depending on the types of organisms that dominate production and the densities of their skeletons. Alternatively, if gross accumulation is calculated according to Harney and Fletcher's (2003) average framework density $\left(1.48 \mathrm{~g} \mathrm{~cm}^{-3}\right)$, the reef flat average is $1.03 \mathrm{~mm} \mathrm{yr}^{-1}$, a similar figure to the $1.15 \mathrm{~mm} \mathrm{yr}^{-1}$ estimate derived using detailed organism densities.

Harney and Fletcher (2003) and Hubbard et al. (1990) report average framework erosion rates (biological plus mechanical) of $27 \%$ and $21 \%$ respectively. Using a $25 \%$ erosion value for Warraber, the mean net vertical framework accumulation on the reef flat is $0.86 \mathrm{~mm} \mathrm{yr}^{-1}$, the same order of magnitude as Harney and Fletcher's (2003) $0.60 \mathrm{~mm} \mathrm{yr}^{-1}$ rate for Kailua Bay and that calculated from Hubbard et al.'s (1990) results for Cane Bay, $0.61 \mathrm{~mm} \mathrm{yr}^{-1}$, but less than Smith's (1983) $3 \mathrm{~mm} \mathrm{yr}^{-1}$ rate for Holocene margin reefs, Stearn et al.'s (1977) $11 \mathrm{~mm}$ $\mathrm{yr}^{-1}$ rate for a rapidly-growing reef, and Buddemeier and Smith's (1988) $10 \mathrm{~mm} \mathrm{yr}^{-1}$ su stained-maximum consensus rate.

Using core samples from the inner reef flat and island, Woodroffe et al. (2000) indicate that the Holocene reef started to grow over Pleistocene foundations $6 \mathrm{~m}$ below the present reef surface around 6,700 yr ago, reaching its present elevation $5300 \mathrm{yr}$ ago, when sea level was 0.8-1.0 m higher than today, thereafter ceasing vertical accumulation. $6 \mathrm{~m}$ of vertical framework accumulation over the 1,400 yr between 6,700 and 5,300 yr ago corresponds to a net vertical accumulation rate on the inner reef flat of $4.29 \mathrm{~mm} \mathrm{yr}^{-1}$, including both framework and sediment material. Assuming the ratio of framework to sediment within the 
reef is around 50:50, as rou ghly ind icated by core composition, and consistent with Buddemeier and Smith (1988), the inner reef flat accumulated framework at an average net rate of $2.14 \mathrm{~m} \mathrm{yr}^{-1}$ from 6,700 to 5,300 yr ago. Both the $2.14 \mathrm{~mm} \mathrm{yr}^{-1}$ 'framework' and 4.29 $\mathrm{mm} \mathrm{yr}^{-1}$ 'total' mid-Holocene accumulation rates for the inner-reef flat are well within the range of contemporary gross framework accumulation rates calculated for the outer reef flat but above those of the inner zones (Fig. 4c). The finding that the emergent inner-reef flat is not presently accumulating is consistent with Woodroffe et al.'s (2000) results.

The contrast between the contemporary lack of inner reef-flat accumulation and the corederived mid-Holocene rates may be explained by intra-platform and regional chan ges in carbonate production conditions as constrained by sea level and pace of reef development. At the reef scale, Woodroffe et al. (2000) describe how the now-central zones 'caught up' with sea level about 5,300 yr ago, followed by stepwise extension s south up to 4,500 yr ago, and subsequent infilling of central areas with ongoing extensions northward. This morphological development would have induced intra-platform changes in physical and growing conditions with increasing distance to the rim for inner areas - at the same time as the regional $0.8-1 \mathrm{~m}$ fall in sea level led to the emergence of the central reef flat, a characteristic which is common on the fringing reefs of the inner GBR. Together, these changes would have caused the nowcentral zones to experience a succession from reef-rim, to lagoon, to outer reef-flat and, finally, to emergent inner-reef-flat environment. Results illustrated in Fig. 4 indicate that such a succession would have been accompanied by large lateral shifts in reef flat ecology and shifts in carbonate production and framework accumulation.

Determining the high-level of variation in framework accumulation rates that exists across the contemporary Warraber reef flat (Fig. 4c) was only made possible using census-based techniques. Results show that the largely-intertidal Warraber reef flat produces approximately two orders of magnitude less carbonate than typical back reef (subtidal) settings. Largelyintertidal reef surfaces are common in the Indo-Pacific, particularly where reefs accreted in keep-up or catch-up growth mode in the mid-Holocene, subsequently being emerged through relative sea-level fall in the late Holocene. Given the spatial extent of the emergent reef platform on Warraber $\left(3.76 \mathrm{~km}^{2}\right.$ or $33 \%$ of reef platform surface), results suggest that global estimates of carbonate productivity should be revised in light of the low productivity of these surfaces and the likelihood that such surfaces cover a substantial proportion of Indo-Pacific reefs.

Extending the census-based geological model into the future, it is possible that climatechange induced sea-level and storminess changes could lead to a partial reversal of Holocene changes in growth conditions across Warraber platform. The extent of this reversal will likely be determined by reef community response to the latter two physical factors, to temperature changes (Buddemeier and Smith 1988) and to the sediment accumulations now occupying the mid-Holocene growth surface.

Buddemeier and Smith (1988) establish an apparent global match between reef growth rates and sea level rise, questioning whether this match is coincidental or functional. The variation in growth rates found between the emergent-inner and deeper-outer reef flat zones on Warraber indicates that the match is, in large part, functional in this setting. This is consistent with Kinsey's (1981) suggestion that the currently-shallow and slow-growing Holocene reef 
flats of the Pacific possess the same potential to increase growth rates in response to accelerated sea level rise as the currently fast-growing Holocene reefs of the Caribbean.

\section{Sediment Implications}

The results of this study have significant implications for interpreting carbonate sinks and their relationship to detrital sediment budgets within reef systems. Fig. 5 contrasts the proportion of total carbonate production contributed by the different reef-flat producers with their occurrence as constituents in the surficial sediments of each zone and, ultimately, in the island beach (Hart 2003). The overall dominance of coral (74\%) and small contribution of molluscs (4\%) to reef-flat production contrast markedly with their representation in beach sediments (coral 8\%, molluscs 55\%). Halimeda is also over-represented in the beach (7\%) relative to its production of carbonate (1\%). Coralline algae $\left(19 \% \mathrm{CaCO}_{3}, 16 \%\right.$ sediment) and foraminifera $\left(2 \% \mathrm{CaCO}_{3}, 5 \%\right.$ sediment) are similar in terms of their carbonate contributions and beach sediment representation. Organism differences between carbonate contributions and surficial reef-flat sediment composition are slightly less than, but of a similar order of magnitude to, those for the island beach (Fig. 5). These differences may be explained by variation s in framework accommodation space (Fig.2), in the spatial distribution of 'direct sediment' and 'framework' production across the reef zones (Fig. 4a), in processes of sediment-particle production (Chave 1964) and taphonomic processes (Scoffin 1992), in particular tran sportability (Folk and Robles 1964; Maiklem 1968), and by spatial separation between carbonate production and sediment-deposition zones (Yamano et al. 2000; Purdy and Gischler 2005).

For example, gastropod tests immediately contribute to the detrital sediment reservoir upon organism mortality and they have higher turnover rates than coral, helping explain their high abundance in reef flat sediments. Furthermore, gastropod tests are of a suitable size for beach nourishment, are predominantly produced in areas close to the island (Zones 1,2,5) where there is little accommodation space and their skeletal architecture make them highly su sceptible to transport (Maiklem 1968; Kench and McLean 1996). Together these factors could explain mollusc dominance of reef-flat and island-beach deposits (Fig. 5) despite their small contribution to total reef flat carbonate production (Table 3).

By contrast, most carbonate production and the vast majority of coral production on Warraber occurs on the outer reef flat (Fig. 4a), which has up to $1 \mathrm{~m}$ of accommodation space (Fig. 2) and, thus, potential for carbonate to be retained as framework. And, although not well quantified, coral has high durability properties related to its architecture (Chave 1964; Folk and Robles 1964; Scoffin 1987), implying relatively-slow conversion rates to sediment, contributing to the dilution of coral in surficial sediments by organisms with higher turnover and sediment-conversion rates (Scoffin 1992).

Furthermore, when coral is eventually broken down it may not be into particle sizes suitable for island-beach nourishment. Coral bioeroders observed on the Warraber reef flat comprised grazing gastropods (Zones 1, 4, 7a-7b), boring bivalves (Zone 3, 6) and Echinometra urchins (Zones 6 and 9). With the exception of bivalves, which can break off large skeletal blocks, these organisms tend to reduce coral to very fine sediment bypassing the sand sizes that comprise the island beach. 
Mechanical erosion of branching coral is more likely to produce sediment suitable for islandbeach maintenance on Warraber. West of the island delicate branches of Montipora digitata and Seriatopora hystrix were observed to be broken off and swept islandward from Zones 8-9 during storm-wave conditions. The amount of carbonate produced on Warraber by branching corals (12\%) which may break into sand-sizes particles is, however, small versus that produced by microatolls ( $59 \%$, Table 3 ) which likely erode into finer particle sizes and which must traverse up to $2 \mathrm{~km}$ of reef surface to contribute to the island deposits.

These initial comparisons indicate that the total amount of carbonate produced on the reef flat is a poor indicator of both the amount and type of carbonate available to be turned into sediment and contribute to sedimentary deposits on reef platforms (e.g., islands, sand aprons and reef-flat sand reservoirs). Clues as to the potential production of beach-nourishing sediment are provided by teasing out the distributions and types of carbonate produced in the different zones of the reef flat. It is recommended that the next step in understanding the relationship between the rates and types of carbonate produced, and the ultimate nature of sink deposits, is to make detailed comparisons between the types, amounts and distribution of carbonate production, and the types and amounts of material found in each reef sink.

Over the longer-term the shifts in reef top ecology discussed and subsequent changes in dominant producers (and rates of production) have major implications for the sediment reservoir and development of geomorphic deposits on reef surfaces. For example, reef islands are unconsolidated accumulations of reef sediment. The accumulation of such islands and their ongoing maintenance is directly dependent on the generation of reef sediments and their tran sport to island shorelines. However, shifts in reef top ecology and carbonate production as identified at Warraber indicate that sediment type and abundance has likely changed over the past 5,000 years. Such shifts may be critical in 'turning on' and 'turning off' reef island formation and in understanding future changes in reef island stability. As shown by and Yamano et al. (2000) ecological shifts in the late Holocene as a consequence of sea level fall leading to reef flat emergence allowed increased production of foraminifera on the Green Island reef surface, possibly triggering the late Holocene development of this foraminiferarich island. In contrast, coral is the dominant constituent comprising many reef islands in the Indo-Pacific (Stoddart and Steers 1977). Of relevance is whether or not islands in settings with emergent reef surfaces, such as Warraber, which curren tly produce only small volumes of coral, are still able to supply sediment to islands in sufficient quantities to maintain island shorelines. In conclusion, the census-based approach examined in this paper has been shown to allow carbonate production values to be established at sub-reef flat scales, thereby providing critical information for evaluating changes in production and organism type available to contribute to the sediment reservoir at locations proximal to reef islands.

\section{Acknowledgements}

Research was supported by an Australian Research Council Grant to CD Woodroffe, PJ Cowell, and RF McLean and University of New South Wales ADFA Postgraduate Research Scholarship to DEH. We thank RF McLean for conceptual advice and field assistance, B Billy, B Samosorn, RW Brander, A Coutts-Smith and GA Stewart for field assistance, W Anderson for statistical advice, T Billy, C Tamu and the people of Warraber Island and 
Beverly and Bill Stephens for their help and hospitality, A Vecsei for supplying raw data from Vecsei (2001), and P Bealing and M Brosnan for assistance with Figures 1 and 3.

\section{References}

Amin M (1978) A statistical analysis of storm surges in Torres Strait. Aust J Mar Freshw Res 29:479-496

Brander RW, Kench PS, Hart DE (2004) Spatial and temporal variations in wave characteristics across a reef platform, Warraber Island, Torres Strait, Australia. Mar Geol 207:169-184

Buddemeier RW and Smith SV (1988) Coral reef growth in an era of rapidly rising sea level: predictions and suggestions for long-term research. Coral Reefs 7:51-56

Cernohorsky WO (1978) Tropical Pacific Marine Shells. Pacific Publications (Aust.) Pty Ltd, Sydney

Chave K (1964) Skeletal Durability and Preservation. In: Imbrie J, Newell N (eds) Approaches to Palaeoecology. John Wiley and Sons Inc, Sydney, pp 377-387

Chave KE, Smith SV, Roy KJ (1972) Carbonate production by coral reefs. Mar Geol 12:123140

Davies PJ, Kinsey DW (1977) Holocene reef growth - One Tree Island, Great Barrier Reef. Mar Geol 24:1-11

Eakin CM (1996) Where have all the carbonates gone? A model comparison of calcium carbonate budgets before and after the 1982-1983 El Niño at Uva Island in the eastern Pacific. Coral Reefs 15:109-119

Folk R, Robles P (1964) Carbonate sands of Isla Perez, Alacran Reef Complex, Yucatan. J Geol 72:255-292

Harney JN (2000) Carbonate Sedimentology of a Windward Shoreface: Kailua Bay, Oahu, Hawaiian Islands. PhD thesis, University of Hawaii, p274

Harney JN, Fletcher CH (2003) A budget of carbonate framework and sediment production, Kailua Bay, Oahu, Hawaii. J Sediment Res 73:856-868

Hart DE (2003) Eco-sedimentologcial environments of an inter-tidal reef platform, Warraber Island, Torres Strait. Ph.D. thesis, University of New South Wales, p220

Hilton AG (1978) Guide to Australian Shells. Robert Brown and Associates Pty Ltd, Port Moresby

Hilton AG (1979) Guide to Shells of Papua New Guinea. Robert Brown and Associates Pty Ltd, Port Moresby

Hopley D (1982) The Geomorphology of the Great Barrier Reef - Quaternary Development of Coral Reefs. Wiley-Interscience Publication, John Wiley and Sons Ltd, New York

Hubbard DK (1985) What do we mean by reef growth? Proc 5th Int Coral Reef Symp 6:433438

Hubbard DK Miller AI, Scaturo D (1990) Production and cycling of calcium carbonate in shelf-edge reef systems (St Croix, U.S. Virgin Islands): Applications to the nature of reef systems in the fossil record. J Sediment Petrol 60:335-360

Hughes TP (1999) Off-reef transport of coral fragments at Lizard Island, Australia. Mar Geol 157:1-6

Jones RW (1994) Challenger Foraminifera. Oxford University Press

Kench PS (1998) Physical controls on development of lagoon sand deposits and lagoon infilling in an Indian Ocean atoll. J Coastal Res 14:1014-1024 
Kench PS, McLean RF (1996) Hydraulic characteristics of heterogeneous bioclastic deposits: new possibilities for interpreting environmental processes. Sedimentology 43:531-540

Kinsey DW (1981) The Pacific/Atlantic Reef growth Controversy. Proc 4th Int Coral Reef Symp 1:493-498

Kinsey DW (1983) Standards of performance in coral reef primary production and carbon turnover. In: Barnes DJ (ed) Perspectives on Coral Reefs. Brian Clouster Publisher, ACT, Australia, pp 209-218

Kinsey DW (1985) Metabolism, calcification and carbon production I. System level studies. Proc 5th Int Coral Reef Symp 6:505-526

Kleypas JA (1997) Modeled estimates of global reef habitat and carbonate production since the last glacial maximum. Paleoceano graphy 12:533-54

Kleypas JA, Buddemeier RW, Archer D, Gattuso JP, Langdon C, Opdyke BN (1999) Geochemical consequences of increased atmospheric carbon dioxide on coral reefs. Science 284:118-120

Macintyre IG, Graus RR, Rein thal PN, Litter MM, Litter DS (1987) The Barrier Reef sediment apron: Tobacco Reef, Belize. Coral Reefs 6:1-12

Maiklem WR (1968) Some hydraulic properties of bioclastic carbonate grains. Sedimentology 10:101-109

Maragos JE, Baines GBK, Beveridge PJ (1973) Tropical Cyclone Bebe creates a new landform on Funafuti Atoll. Science 181:1161-1164

Milliman JD (1993) Production and accumulation of calcium carbonate in the ocean: budget of a nonsteady state. Global Biogeochem Cycles 7:927-957

Odum HT, Odum EP (1955) Trophic structure and productivity of windward coral reef community on Eniwetok Atoll. Ecol Monogr 25:291-320

Puotinen ML (2004) Tropical cyclone impacts on reef communities: Modelling the disturbance regime in the Great Barrier Reef region, 1969-2003. PhD thesis, James Cook University, Town sville, p229

Purdy EG, Gischler E (2005) The transient nature of the empty bucket model of reef sedimentation. Sediment Geol 175:35-47

Ryan DA, Opdyke BN, Jell JS (2001) Holocene sediments of Wistari Reef: towards a global quantification of coral reef related neritic sedimentation in the Holocene. Palaeogeogr Palaeoclimatol Palaeoecol 175:173-184

Sadd JL (1984) Sediment transport and $\mathrm{CaCO}_{3}$ budget on a fringing reef, Cane Bay, St Croix, U.S. Virgin Islands. Bull Mar Sci 35:221-238

Scoffin TP (1987) Introduction to Carbonate Sediments and Rocks. Blackwell, Glasgow

Scoffin TP (1992) Taphonomy of coral reefs: a review. Coral Reefs 11:57-77

Scoffin TP, Garrett P (1974) Processes in the formation and preservation of internal structure in Bermuda patch reefs. Proc 2nd Int Coral Reef Symp 2:429-448

Scoffin TP, Stearn CW, Boucher D, Frydl P, Hawkins CM, Hunter IG, MacGeachy JK (1980) Calcium carbonate budget of a fringing reef on the west coast of Barbados. Bull Mar Sci 30:475-508

Short JW, Potter DG (1987) Shells of Queensland and the Great Barrier Reef. Golden Press Pty. Limited, Drummoyne, NSW

Smith SV (1981) The Houtman Abrolhos Islands: carbon metabolism of coral reefs at high latitudes. Limnol Oceanogr 26:612-621

Smith SV (1983) Coral reef calcification. In: Barnes DJ (ed) Perspectives on Coral Reefs. Brian Clouster Publisher, ACT, Australia, pp 240-247 
Smith SV, Harrison JT (1977) Calcium carbonate production of the Mare Incognitum, the upper windward reef slope, at Enewetak Atoll. Science 197:556-559

Smith SV, Kinsey DW (1976) Calcium carbonate production, coral reef growth and sea level change. Science 194:937-939

Smith SV, Kinsey DW (1978) Calcification and organic carbon metabolism as indicated by carbon dioxide. In: Stoddart DR, Johannes RE (eds) Coral Reefs: Research Methods. UNESCO, Monographs on Oceanographic Methodology. Paris 5:469-484

Stearn CW, Scoffin TP, Martindale W (1977) Calcium carbonate budget of a fringing reef on the west coast of Barbados. Bull Mar Sci 27:479-510

Stoddart DR, Steers JA (1977) The nature and origin of coral reef islands. In: Jones OA, Endean R (ed) Biology and geology of coral reefs, vol 4, Geol 2. Academic Press, New York, pp 59-105

Vecsei A (2001) Fore-reef carbonate production: development of a regional census-based method and first estimates. Palaeogeogr Palaeoclimatol Palaeoecol 175:185-200

Vecsei A (2004) A new estimate of global reefal carbonate production including the forereefs. Global Planet Change 43:1-18

Veron JEN (1986) Corals of Australia and the Indo-Pacific. Angus and Robertson Publishers, North Ryde, NSW, Australia

Veron JEN (2000) Corals of the World (3 vol.). Australian Institute of Marine Science, Townsville, Australia

Wilson BR, Gillett K (1971) Au stralian Shells. AH and AW Reed, Sydney

Wood EM (1983) Reef Corals of the World. T.F.H. Publications, Neptune City

Woodroffe C, McLean RF, Smithers SG, Lawson EM (1999) Atoll reef-island formation and response to sea-level chan ge: West Island, Cocos (Keeling) Islands. Mar Geol 160:85-104

Woodroffe CD, Kennedy DM, Hopley D, Rasmussen CE, Smithers SG (2000) Holocene reef growth in Torres Strait. Mar Geol 170:331-346

Yamano H, Miyajima T, Koike I (2000) Importance of foraminifera for the formation and maintenance of a coral sand cay: Green Island, the Great Barrier Reef, Australia. Coral Reefs 19:51-58

Yamano H, Kayanne H, Matsuda F, Tsuji Y(2002) Lagoonal facies, ages, and sedimentation in three atolls in the Pacific. Mar Geol 185:233-247

Young IR, Holland GJ (1996) Atlas of the Oceans:Wind and Wave Climate. Elsevier Science Ltd, Oxford

Zar JH (1999) Biostatistical Analysis $4^{\text {th }}$ Edn. Prentice Hall, New Jersey 


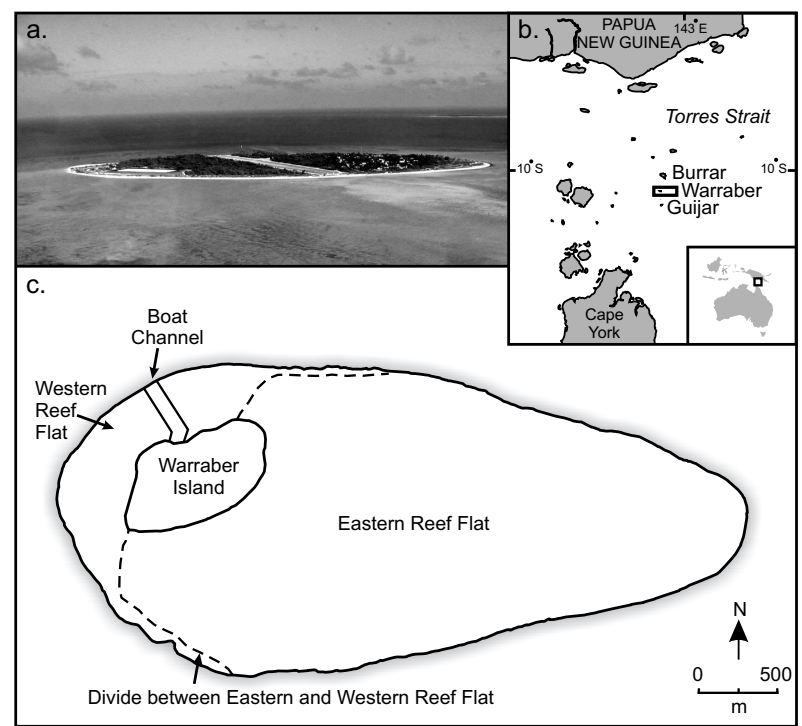

Fig. 1 Image and maps showing (a) Warraber Island, (b) its location in The Three Sisters reef group, Central Torres Strait, Australia, and (c) the main features of the Warraber Reef platform

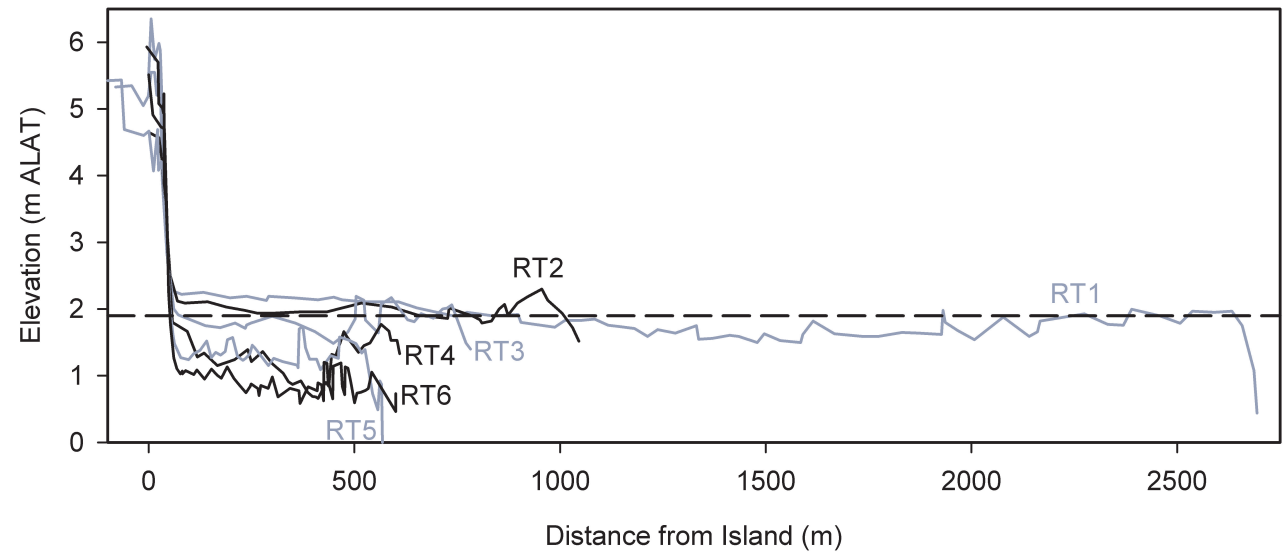

Fig. 2 Topographic surveys of the reef flat transects in relation to mean sea level (i.e. the dotted line at $1.9 \mathrm{~m}$ above the lowest astrono mic al tide, ALAT) 


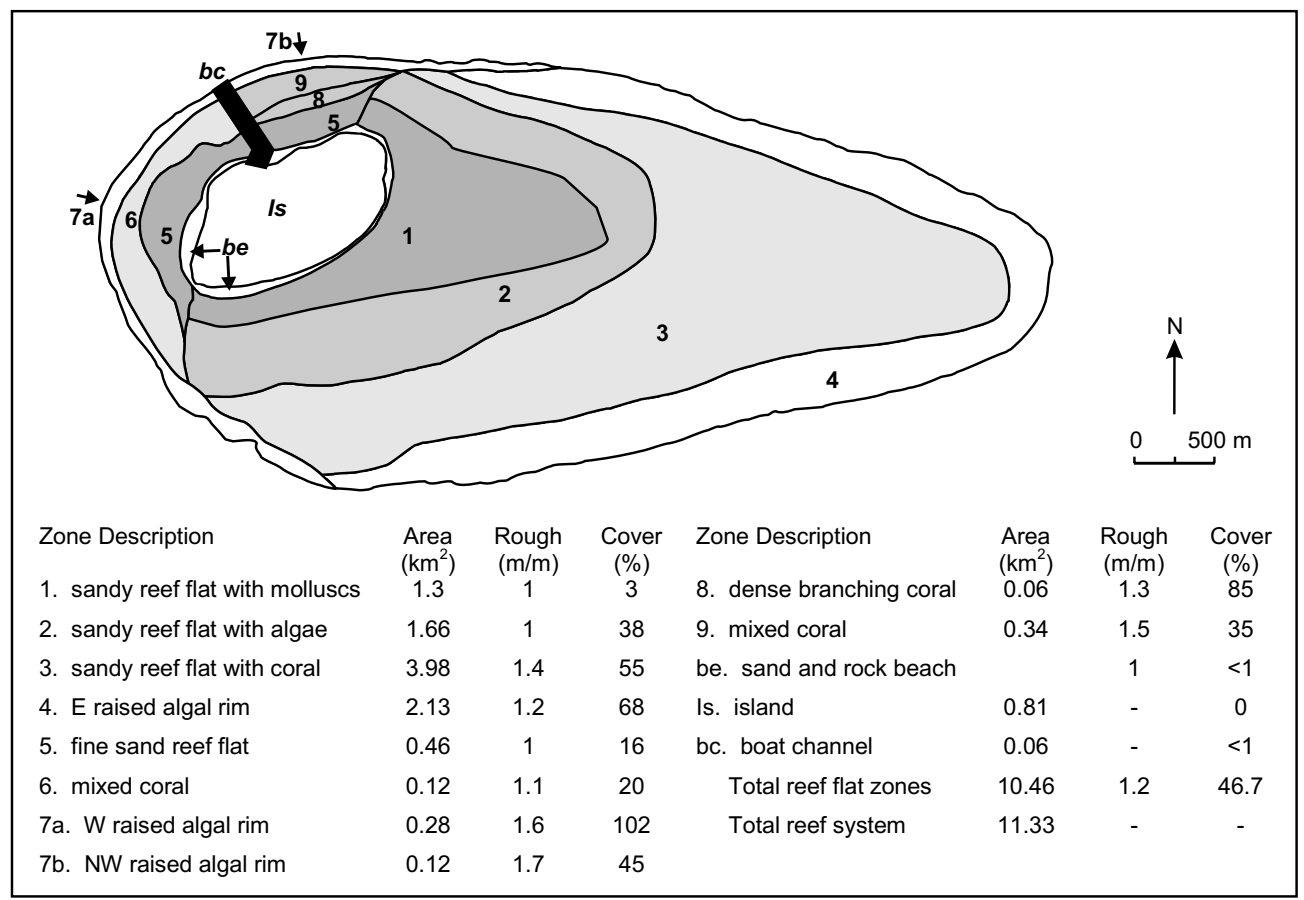

Fig. 3 Map and description of the ten identified ecologic al zones of the Warraber reef flat, includ ing area, roughness and covercharacteristic $\mathrm{s}$ 


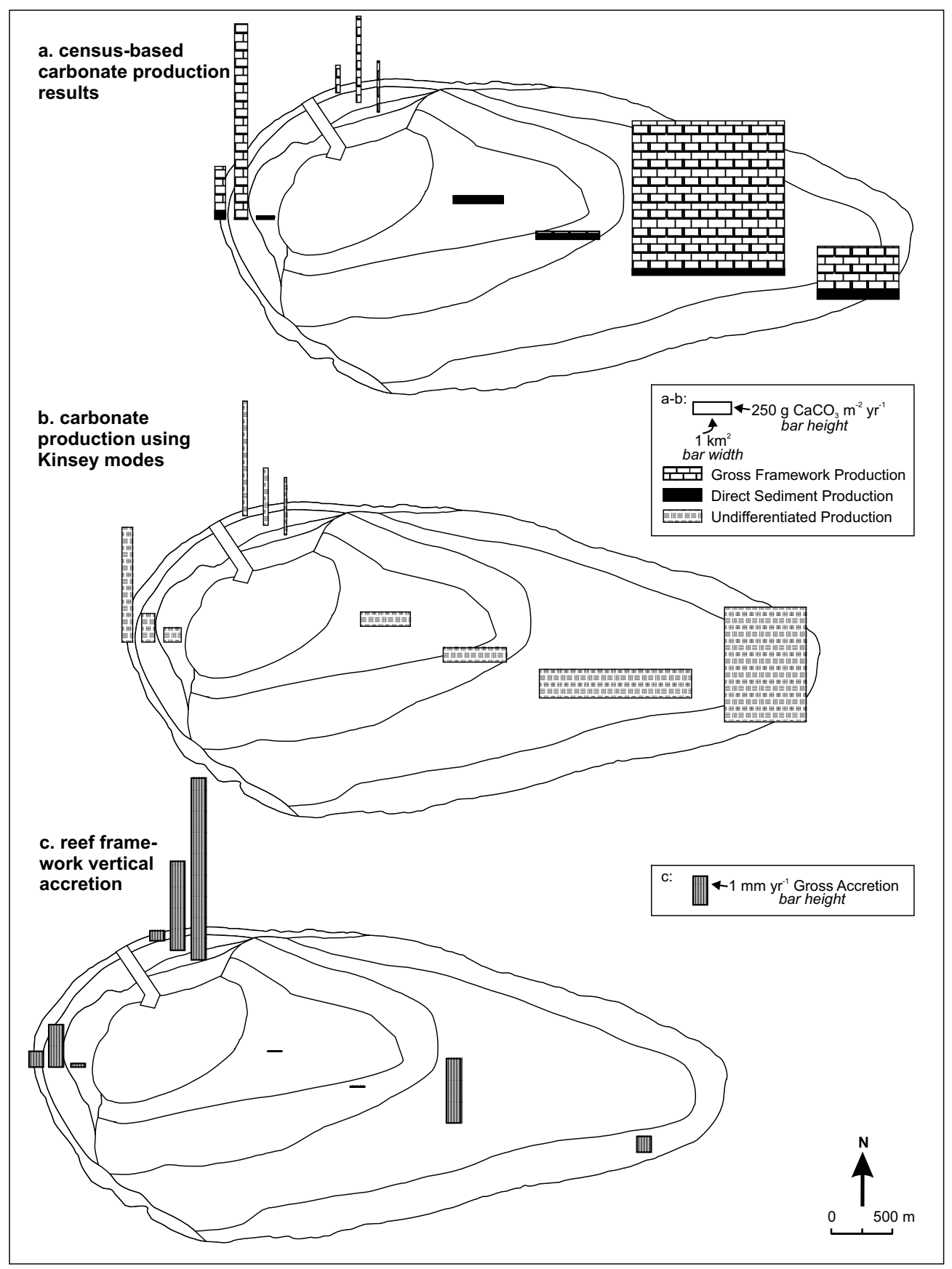

Fig. 4 Carbonate production rates (bar height) and amounts (bar area) in the ten ecological zones of the Warraber reef flat es timated using census-based techniques (a) versus modes derived from Kinsey's (1983, 1985) alka linity-reduction review (b), and gross vertical framework accumulation rates calculated for the ten ecologic al zones based on framework building organ is m cover, production and density 


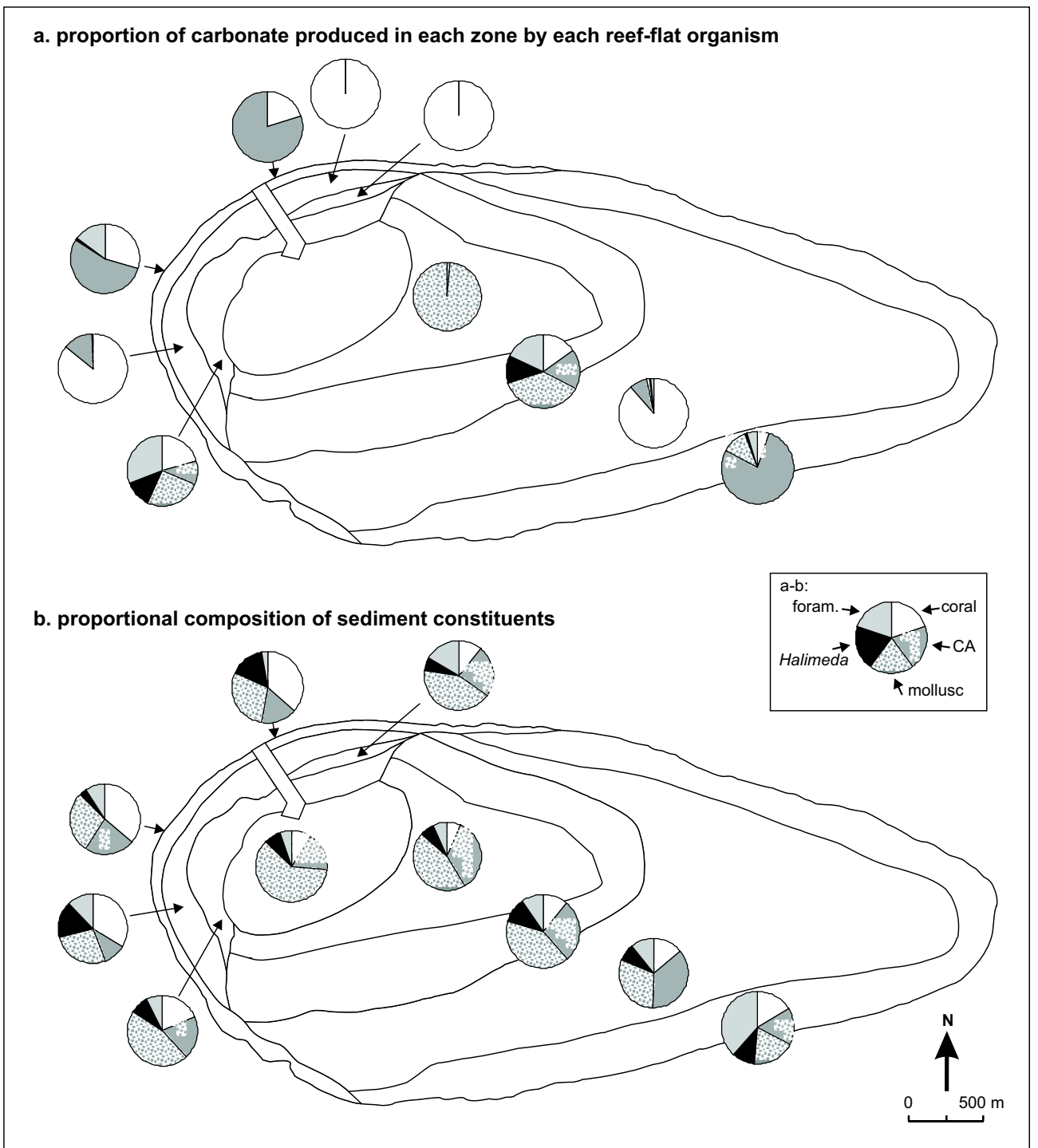

Fig. 5 Proportion of carbonate production contributed by the five main producers (a) versus the constituent composition of sediments (b) within each ecologic al zone of the reef flat. Note foram. abbreviates foraminifera 
Table 1 Results from analys is of variance tests for (a) cover by quadrat versus by site, (b) cover by site within transect and (c) cover by site versus by transect

\begin{tabular}{|c|c|c|c|c|c|c|c|c|}
\hline \multirow[t]{2}{*}{ Cover type } & \multicolumn{2}{|c|}{$\begin{array}{l}\text { a) Single Factor } \\
\text { ANOVA* } \\
\text { Site between } \\
\text { transect }\end{array}$} & \multirow{2}{*}{$\begin{array}{l}\text { a) Monte Carlo } \\
\text { Randomis ation } \\
\text { P-value }\end{array}$} & \multicolumn{2}{|c|}{$\begin{array}{l}\text { b) Single Factor } \\
\text { ANOVA* } \\
\text { Site within } \\
\text { transect }\end{array}$} & \multicolumn{2}{|c|}{$\begin{array}{l}\text { c) Single Factor } \\
\text { ANOVA** } \\
\text { Site versus } \\
\text { transect }\end{array}$} & \multirow{2}{*}{$\begin{array}{l}\text { c) Monte Carlo } \\
\text { Randomisation } \\
\text { P-value }\end{array}$} \\
\hline & $\mathrm{F}$ & P-value & & $\mathrm{F}$ & $\mathrm{P}$-value & $\mathrm{F}$ & P-value & \\
\hline $\begin{array}{c}\text { Coral-ramose- } \\
\text { other }\end{array}$ & 18.079 & $<0.001$ & 0 & 15.162 & $<0.001$ & 2.732 & 0.046 & 0.041 \\
\hline $\begin{array}{c}\text { Coral-ramose- } \\
\text { Acropora }\end{array}$ & 2.870 & $<0.001$ & 0.003 & 2.578 & $<0.001$ & 2.022 & 0.115 & 0.102 \\
\hline Coral-massive & 1.358 & 0.133 & 0.089 & 1.428 & 0.106 & 0.559 & 0.694 & 0.733 \\
\hline $\begin{array}{c}\text { Coral- } \\
\text { fol/encr } / \mathrm{mu}\end{array}$ & 1.007 & 0.476 & 0.188 & 0.948 & 0.555 & 1.564 & 0.208 & 0.162 \\
\hline Halimeda & 1.885 & 0.011 & 0.022 & 1.834 & 0.017 & 1.247 & 0.311 & 0.298 \\
\hline CA-encr & 12.452 & $<0.001$ & 0 & 12.566 & $<0.001$ & 0.919 & 0.465 & 0.515 \\
\hline CA-artic & 3.875 & $<0.001$ & $<0.001$ & 3.936 & $<0.001$ & 0.861 & 0.498 & 0.493 \\
\hline Mollusc & 9.957 & $<0.001$ & 0 & 9.138 & $<0.001$ & 1.807 & 0.152 & 0.138 \\
\hline Foraminifera & 1.714 & 0.026 & 0.039 & 1.590 & 0.052 & 1.701 & 0.174 & 0.166 \\
\hline Brown algae & 6.125 & $<0.001$ & 0 & 5.906 & $<0.001$ & 1.333 & 0.279 & 0.274 \\
\hline Sponge & 2.696 & $<0.001$ & 0.002 & 2.774 & $<0.001$ & 0.745 & 0.569 & 0.588 \\
\hline Sea grass & 1.891 & 0.011 & 0.019 & 2.019 & 0.007 & 0.43 & 0.786 & 0.902 \\
\hline
\end{tabular}

* degrees of freedom with in groups $=74$, degrees of freedom between groups $=36, \mathrm{n}=111$, confidence level $=0.95$

$* *$ degrees of freedom within groups $=32$, degrees of freedom between groups $=4, n=37$, confidence level $=0.95$

Table 2 Estimated calcific ation rates used to calculate carbonate production on the Warraber reef flat as derived from a review of published rates (see Appendix 1 for details)

\begin{tabular}{|c|c|c|c|}
\hline Organism & $\begin{array}{l}\text { Best-es timate } \\
\text { calcific ation rate } \\
\left(\mathrm{g} \mathrm{m}^{-2} \mathrm{yr}^{-1}\right)\end{array}$ & $\begin{array}{l}\text { Minimum to maximum } \\
\text { calc ification rates } \\
\left(\mathrm{g} \mathrm{m}^{-2} \mathrm{yr}^{-1}\right)\end{array}$ & Adjustment factor \\
\hline Coralline algae & 1,872 & $1,500-2,500$ & $\begin{array}{l}\text { multiplied by the square of quadrat } \\
\text { rugosity for crustose spec ies }\end{array}$ \\
\hline Coral massive & 16,160 & $7,680-24,640$ & \\
\hline Coral-fol/encr/mu & 17,000 & $3,000-31,000$ & \\
\hline Coral ramos e-Acropora & 19,242 & $10,818-27,666$ & $\begin{array}{l}\text { multip lied by an effective cover } \\
\text { factor of } 0.25\end{array}$ \\
\hline Coral ramose-other & 1,394 & $767-2,021$ & $\begin{array}{l}\text { multiplied by a branch extension } \\
\text { factor of } 0.4\end{array}$ \\
\hline Halimeda & 1,066 & $400-1,667$ & \\
\hline foraminife ra & 120 & $30-230$ & $\begin{array}{l}\text { multiplied by a factor of between } 0 \text { - } \\
3 \text { depending on organism density }\end{array}$ \\
\hline molluscs & 100 & $10-200$ & $\begin{array}{l}\text { multiplied by a factor of between } 0 \text { - } \\
3 \text { depending on organism density }\end{array}$ \\
\hline
\end{tabular}


Table 3 Gross carbonate production rates (a) and amounts (b) by producer type across the ten ecological zones of the Warraber reef flat calculated using the best-estimate calcification rates. Cover ${ }^{b}$ is the percentage of area occupied by carbonate producers, which compris es $23 \%$ or $2.41 \mathrm{~km}^{2}$ of the reef flat. SD is standard deviation

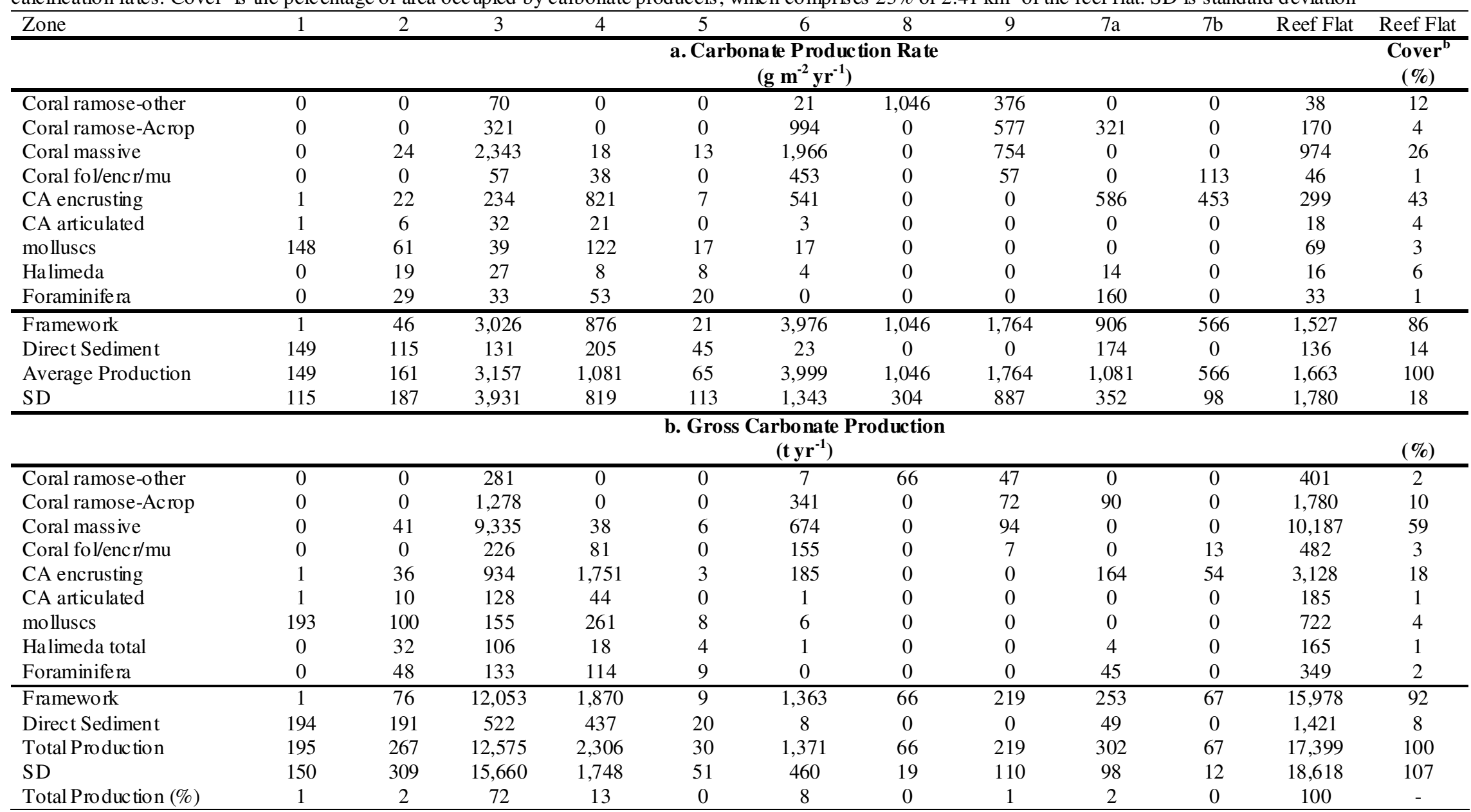


Table 4 Estimated amounts and proportions of carbonate produced by the different types of organism on Warraber determined using the best estimate (mean), minimum and maximum calcification rates

\begin{tabular}{ccccccc}
\hline & \multicolumn{2}{c}{$\mathrm{CaCO}_{3}$ production $\left({\left.\mathrm{t} \mathrm{yr}^{-1}\right)}^{-1}\right.$} & \multicolumn{3}{c}{$\mathrm{CaCO}_{3}$ production (\%) } \\
& Mean & Maximum & Minimum & Mean & Maximum & Minimum \\
\hline CA encrusting & 3,128 & 4,177 & 1,282 & 18 & 16 & 17 \\
CA articulated & 185 & 248 & 76 & 1 & 1 & 1 \\
Coral ramose-o ther & 401 & 581 & 221 & 2 & 2 & 3 \\
Coral ramose-Acrop & 1,780 & 2,559 & 1,001 & 10 & 10 & 13 \\
Co ral massive & 10,187 & 15,533 & 4,842 & 59 & 59 & 63 \\
Coral fol/encr/mu & 482 & 879 & 85 & 3 & 3 & 1 \\
Halimeda total & 165 & 258 & 62 & 1 & 1 & 1 \\
molluscs & 722 & 1,444 & 72 & 4 & 5 & 1 \\
Foraminifera & 349 & 668 & 87 & 2 & 3 & 1 \\
\hline Total & 17,399 & 26,347 & 7,726 & 100 & 100 & 100 \\
\hline
\end{tabular}


Table 5 Comparison of carbonate-production estimates for the Warraber reef flat with published rates from several reef environments

\begin{tabular}{|c|c|c|c|c|c|c|}
\hline Loc ation & Reef Environment & Method & $\begin{array}{l}\text { Carbonate Production } \\
\left(\mathrm{kg} \mathrm{CaCO}_{3} \mathrm{~m}^{-2} \mathrm{yr}^{-1}\right)\end{array}$ & Study area & $\begin{array}{l}\text { Total production } \\
\left({\left.\mathrm{t} \mathrm{yr}^{-1}\right)}\right.\end{array}$ & Source \\
\hline $\begin{array}{l}\text { Warraber Is land, } \\
\text { Torres Strait }\end{array}$ & $0-4 \mathrm{~m}$ deep inter-tidal reef flat & census -based & 1.66 & $10,462,700 \mathrm{~m}^{2}$ & $17,399 \pm 18,618$ & present study \\
\hline $\begin{array}{l}\text { Green Island, } \\
\text { Great Barrier Reef }\end{array}$ & reef flat and slope & census - b ased & $1.6-3.9 *$ & $410,000 \mathrm{~m}^{2}$ & $656-1,606$ & Yamano et al. 2000 \\
\hline $\begin{array}{l}\text { Mode of Several } \\
\text { Pacific Reefs }\end{array}$ & 1-3 m deep, seaward reef flat & alkalin ity-reduction & 4 & - & - & Smith and Kins ey 1976 \\
\hline $\begin{array}{l}\text { Mode of Several } \\
\text { Pacific Reefs }\end{array}$ & protec ted 5-6 m deep lagoon/bank & alkalin ity-reduction & 0.8 & - & - & Smith and Kins ey 1976 \\
\hline $\begin{array}{l}\text { Japtan Inter-Is land } \\
\text { Reef, Eniwetok }\end{array}$ & inter-is land reef flat & c ens us $-b$ ased & 30.5 & $\begin{array}{l}455 \mathrm{~m} \text { long } \\
\text { transect }\end{array}$ & - & Odum and Odum 1955 \\
\hline $\begin{array}{l}\text { Kailua Bay, } \\
\text { Hawaii }\end{array}$ & $\begin{array}{l}\text { fringing reef with large sand bodies } \\
\text { and a diverse benthic community }\end{array}$ & c ens us $-b$ as ed & 3.18 & $10,000,000 \mathrm{~m}^{2}$ & $74,810 \pm 7,440$ & Harney 2000 \\
\hline $\begin{array}{l}\text { Kaneohe Bay, } \\
\text { Hawaii }\end{array}$ & shallow $(<3 \mathrm{~m})$ reef flat & alkalin ity-reduction & $\begin{array}{c}4.7 \\
(3.5-8)\end{array}$ & $\begin{array}{l}200 \mathrm{~m} \text { long } \\
\text { transect }\end{array}$ & - & Kinsey 1981 \\
\hline $\begin{array}{l}\text { Discovery Bay, } \\
\text { Jamaica }\end{array}$ & shallow $(<3 \mathrm{~m})$ reef flat & alkalinity-reduction & $\begin{array}{c}4.4 \\
(1.2-10)\end{array}$ & $\begin{array}{l}200 \mathrm{~m} \text { long } \\
\text { transect }\end{array}$ & - & Kinsey 1981 \\
\hline $\begin{array}{l}\text { Bellairs Reef, } \\
\text { Barbados }\end{array}$ & $5 \mathrm{~m}$ deep fring ing reef & census $-b$ as ed & 15 & $10,800 \mathrm{~m}^{2}$ & 163 & Stearn et al. 1977 \\
\hline $\begin{array}{l}\text { Cane Bay, St. Croix } \\
\text { Virgin Islands }\end{array}$ & $\begin{array}{l}\text { fringing reef } 2-60 \mathrm{~m} \text { deep incl. hard } \\
\text { ground, reef flat and slope }\end{array}$ & c ens us $-b$ as ed & $\begin{array}{c}1.9 \\
(0.85-5.0)\end{array}$ & $30,000 \mathrm{~m}^{2}$ & 57.5 & Sadd 1984 \\
\hline $\begin{array}{l}\text { Cane Bay, St. Croix } \\
\text { Virgin Islands }\end{array}$ & $\begin{array}{l}\text { fringing reef shelf, } 0-40 \mathrm{~m} \text { deep incl. } \\
\text { reef flat, slope and shelf }\end{array}$ & census -based & $\begin{array}{c}1.21 \\
(0-5.78)\end{array}$ & $412,200 \mathrm{~m}^{2}$ & $499 *$ & Hubbard et al. 1990 \\
\hline hypothetical & reef flat & c ens us $-b$ as ed & 3 & - & - & Chave et al. 1972 \\
\hline hypothetical & lagoon & c ens us - b ased & 5 & - & - & Chave et al. 1972 \\
\hline hypothetical & algal ridge & c ens us - b ased & 9 & - & - & Chave et al. 1972 \\
\hline hypothetical & upper slope & c ens us -bas ed & 60 & - & - & Chave et al. 1972 \\
\hline hypothetical & lower slope & c ensus $-b$ as ed & 8 & - & - & Chave et al. 1972 \\
\hline
\end{tabular}




\section{Appendix 1. Overview of organism calcification rates and factors used to estimate carbonate production on the Warraber reef flat}

The published growth and carbonate production rates that underpin the censusbased method are reviewed below for the five main producers present on Warraber, corals, coralline algae, molluscs, foraminifera and Halimeda, in order to determine appropriate calcification rates and factors.

\section{Coralline algae}

Published estimates of the coralline algal calcification rates vary by an order of magnitude, although most rates lie between 1,500-2,500 $\mathrm{g} \mathrm{m}^{-2} \mathrm{yr}^{-1}$ (Table A1). Variation arises due to differences in (a) the growth rates of individual species, (b) physical habitat suitability, and (c) predation intensity (Adey and Vassar 1975; Stearn et al. 1977). In general, coralline algal calcification is highest in shallowwater habitats and in areas with minimal grazing, particularly by parrot fish (Eakin 1996; Adey and Vassar 1975).

Table A1 Published es timates of coralline algae extension and gross calcification for various reef environments

a calculated using Stearn et al.'s (1977) density of $1.56 \mathrm{~g} \mathrm{~cm}^{-3}$

\begin{tabular}{lccl}
\hline Reef Environment & $\begin{array}{c}\text { Extension rate } \\
\left(\mathrm{mm} \mathrm{yr}^{-1}\right)\end{array}$ & $\begin{array}{c}\text { Calcific ation } \\
\left(\mathrm{g} \mathrm{CaCO}_{3} \mathrm{~m}^{-2} \mathrm{yr}^{-1}\right)\end{array}$ & Source \\
\hline algal ridge and reef, Virg in Is lands & $1-5.2$ & $1,560-8,112^{\mathrm{a}}$ & Adey \& Vassar 1975 \\
fore-reef, Barbados & $0.1-1.5$ & $167-2,378$ & Stearn et al. 1977 \\
upper fore-reef and reef crest, Jap an & $1.0-1.2$ & $1,560-1,872^{\mathrm{a}}$ & Matsuda 1989 \\
mostly reef flat, Panama & 1.9 & 1,872 & Eakin 1992 \\
\hline
\end{tabular}

The flat-surface calcification rate $1,872 \mathrm{~g} \mathrm{~m}^{-2} \mathrm{yr}^{-1}$ was used in this study to calculate coralline algal production rates. This value was derived by multiplying Matsuda's (1989) moderate, Pacific, reef-flat extension rate $\left(1.2 \mathrm{~mm} \mathrm{yr}^{-1}\right)$ by Stearn et al.'s (1977) measure of the bulk skeletal density of coralline algae (1.56 $\left.\mathrm{g} \mathrm{cm}^{-1}\right)$ and is similar to that found in other Pacific shallow reef environments (Table A1). Reflecting the majority of published estimates, the calcification rates $1,500 \mathrm{~g} \mathrm{~m}^{-2} \mathrm{yr}^{-1}$ and 2,500 $\mathrm{g} \mathrm{m}^{-2} \mathrm{yr}^{-1}$ were used as minimum and maximum estimates of calcification. Calcification of crustose coralline algae in a given quadrat $\left(\mathrm{g} \mathrm{m}^{-2} \mathrm{yr}^{-1}\right)$ was calculated by multiplying this flat-surface calcification rate $\left(\mathrm{g} \mathrm{m}^{-2} \mathrm{yr}^{-1}\right)$ by the percentage cover and the square of quadrat rugosity, as suggested by Eakin (1996).

\section{Coral}

The numerous extension rates of Pacific corals reported by Vecsei (2001), and other authors, form the primary source of data on coral calcification employed in this study (Table A2). These data indicate that Pacific coral growth rates vary by two orders of magnitude depending on the species, growth form and environment studied. Published shallow-water $(<10 \mathrm{~m})$ coral extension rates were grouped into four categories: i) massive; ii) foliaceous, encrusting and mushroom (fol/encr/mu); iii) ramose-Acropora; and iv) ramose-other (after Vecsei 2001). Best-estimate (mean), minimum (mean $-1 \sigma$ ) and maximum $($ mean $+1 \sigma)$ extension rates were calculated for each category (Table A2). Ramose-Acropora 
rates were further multiplied by a factor of 0.4 (Graus et al. 1977; Bottjer 1980) to account for the difference between extension perpendicular to the cover surface (ie. linear), and that along branches.

The observed cover data from Warraber were multiplied by an estimate of the effective cover for each growth form (1 for massive, foliaceous, encrusting and mushroom colonies and 0.25 for ramose-Acropora and ramose-other) (after Vecsei 2001). Carbonate production rates were then calculated by multiplying the adjusted cover data by the published densities and calculated extension rates of each coral category (Table A2) and results were summed to give the estimated production of corals in each quadrat $\left(\mathrm{g} \mathrm{m}^{-2} \mathrm{yr}^{-1}\right)$.

\section{Halimeda}

Table A3 presents published growth rates for the green alga Halimeda and indicates that rates vary depending upon the measurement technique, species and plant density or biomass per unit area. Alkalinity-reduction methods can lead to over-estimation of calcification, while those reliant on segment staining and tagging produce minimum estimates since any new segments lost are not accounted for (Multer 1988; Payri 1988). Discrete, rhipsalian, sand-d welling Halimeda species produce up to an order of magnitude less calcium carbonate per square meter than sprawling, lithophytic species (Hillis-Colinvaux 1974; Drew 1983; Multer 1988; Payri 1988).

The majority (>95\%) of Halimeda plants found on Warraber were of the rhipsalian, sand-dwelling, slow-growing variety while the maximum observed plant density found in quadrats was 40 plants or $15 \%$ cover. An estimated calcification rate of $160 \mathrm{~g} \mathrm{~m}^{-2} \mathrm{yr}^{-1}$ per $15 \%$ cover (or $1,066 \mathrm{~g} \mathrm{~m}^{-2} \mathrm{yr}^{-1}$ for $100 \%$ cover) was used to calculate the production rate of Halimeda in survey quadrats. Minimum and maximum estimates of 60 and $250 \mathrm{~g} \mathrm{~m}^{-2} \mathrm{yr}^{-1}$ of calcification per $15 \%$ cover (400 and $1,667 \mathrm{~g} \mathrm{~m}^{-2} \mathrm{yr}^{-1}$ for $100 \%$ cover) were used to test the sensitivity of the total carbonate production figures to Halimeda production rates, taking into account potential variation in local growth rates and in the exact ratio of rhipsalian to lithophytic species present in the different reef flat subenvironments. 
Table A2 Coral ex tension rates, skeletal density and calcification rates used in calculating carbonate production on Warraber. Most values are from sites in the Pacific Ocean with a few values from sites in the Indian Ocean, Red Sea and, for foliaceous corals, from the Atlantic. Standard deviations ( $\sigma$ ) are given after \pm and the number of observations is ind ic ated by $\mathrm{n}$

${ }^{\mathrm{a}}$ cited in Huston $(1985,22)$

${ }^{\mathrm{b}}$ multiplied by an effective cover factor of 0.25

${ }^{c}$ multiplied by a branch extension factor of 0.4

\begin{tabular}{|c|c|c|c|c|c|c|}
\hline Category & $\begin{array}{l}\text { Extension } \\
\left(\mathrm{mm} \mathrm{yr}^{-1}\right)\end{array}$ & Range & Sources & $\begin{array}{c}\text { Density } \\
\left(\mathrm{g} \mathrm{CaCO}_{3} \mathrm{~cm}^{-3}\right)\end{array}$ & Source & $\begin{array}{c}\text { Calcification } \\
\left(\mathrm{g} \mathrm{CaCO}_{3} \mathrm{~m}^{-2} \mathrm{yr}^{-1}\right)\end{array}$ \\
\hline massive & $10.1 \pm 5.3$ & $\begin{array}{c}1.4-32 \\
(n=110)\end{array}$ & $\begin{array}{l}\text { Mayor } 1924 \text { a; Knutson et al. 1972; Buddemeier et al. } \\
\text { 1975; Highs mith 1979; Grigg 1982; Welling ton 1982; } \\
\text { Wellington and Glynn 1983; Charuchinda and } \\
\text { Chansang 1985; Hughes 1987; Guzman and Cortes } \\
\text { 1989; Scoffin et al. 1992; Kle in et al. 1993; Glynn et al. } \\
\text { 1996; Stimson 1996; Vecsei 2001 }\end{array}$ & 1.6 & Hughes 1987 & $16,160 \pm 8,480$ \\
\hline $\begin{array}{l}\text { foliaceous, mushroom } \\
\text { and encrusting }\end{array}$ & $8.5 \pm 7$ & $\begin{array}{l}0.8-23 \\
(\mathrm{n}=20)\end{array}$ & $\begin{array}{l}\text { Mayor } 1924^{\mathrm{a}} \text {; Edmondson } 1929^{\mathrm{a}} \text {; Wellington } 1982 \text {; } \\
\text { Hughes and Jackson 1985; Hus ton 1985; Stims on } 1996\end{array}$ & 2.0 & Hughes 1987 & $17,000 \pm 14,000$ \\
\hline ramose - Acropora & $106.9 \pm 46.8$ & $\begin{array}{l}4-185 \\
(n=18)\end{array}$ & $\begin{array}{c}\text { Mayor } 1924^{\text {a }} \text {; Cross land 1981; Oliver et al. 1983; } \\
\text { Charuchinda and Hylleberg 1984; Yap and Gomez } \\
\text { 1984; Marsh 1993; Stimson 1996; Harriott 1998; } \\
\text { Vecsei 2001 }\end{array}$ & 1.8 & $\begin{array}{l}\text { Schuhmacher and } \\
\text { Plewka } 1981\end{array}$ & $19,242 \pm 8,424^{\mathrm{bc}}$ \\
\hline ramose-other & $33.8 \pm 15.2$ & $\begin{array}{l}6-72 \\
(\mathrm{n}=21)\end{array}$ & $\begin{array}{l}\text { Mayor } 1924^{\text {a }} \text {; Glynn 1976; Neudecker 1977; Glynn and } \\
\text { Stewart 1973; Wellington 1982; Vecsei } 2001\end{array}$ & 0.165 & Eakin 1992, 1996 & $1,394 \pm 627^{b}$ \\
\hline
\end{tabular}

Table A3 Published mean growth and calcification rates of vario us types of Halimeda species at different dens ities in different types of environment

\begin{tabular}{|c|c|c|c|c|c|c|}
\hline Species & Type & Environment & Method & $\begin{array}{l}\text { Biomass or } \\
\text { Density }\end{array}$ & $\begin{array}{c}\text { Calcification } \\
\left(\mathrm{g} \mathrm{CaCO}_{3} \mathrm{~m}^{-2} \mathrm{yr}^{-}\right.\end{array}$ & Source \\
\hline H. incrassata & rhipsalian & shallow lagoon, Bermuda & s egment staining & $6.7 \mathrm{~g} \mathrm{~m}^{-2}$ & 50 & Wefer 1980 \\
\hline$H$. incrassata and $H$. monile & rhipsalian & barrier reef, Antigua & segment staining & 36 plants $\mathrm{m}^{-2}$ & 114 & Multer 1988 \\
\hline$H$. incrassata and $H$. monile & rhipsalian & fringing lagoon, Antigua & segment staining & 30 plants $\mathrm{m}^{-2}$ & 62 & Multer 1988 \\
\hline H. incrassata and H. monile & rhip salian & open lagoon, Antigua & segment staining & 26 plants $\mathrm{m}^{-2}$ & 61 & Multer 1988 \\
\hline H opuntia & lithophytic & lagoon, Florida & s egment staining & $\begin{array}{c}1 \text { plant } \mathrm{m}^{-2} \\
\left.\text { (c. } 1,200 \mathrm{~g} / \mathrm{m}^{2}\right)\end{array}$ & 1,088 & Hudson 1985 \\
\hline
\end{tabular}




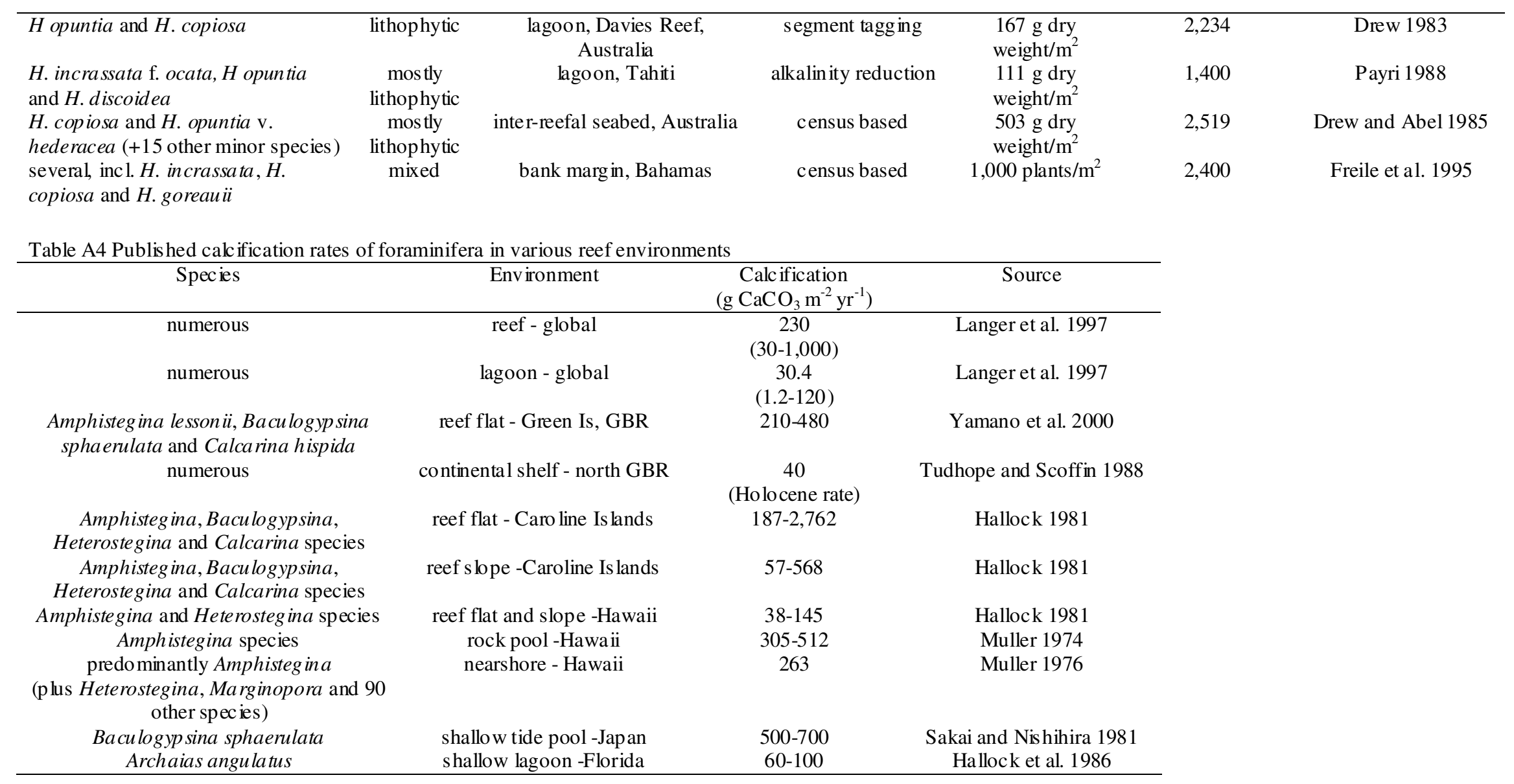




\section{Foraminifera}

In the majority of reef carbonate budget studies foraminiferal contributions are excluded (Stearn et al. 1977; Eakin 1996), determined from the volume of tests in sediments (Hubbard et al. 1990), or gauged from global estimates (Vecsei 2001). Published estimates of reef foraminifera calcification rates vary considerably depending on the species and environment studied (Table A4). On Warraber, live tests of the larger, more productive foraminifera (Marginopora vertebralis, $M$. vertebralis var. plicata, Amphisorus hemprichii) were observed in small numbers in quadrats where they were present while abundant tests of the smaller, lessproductive species (Amphistegina lessonii, Baculogypsina sphaerulata, Calcarina spengleri) were found where these species were present. Overall, a mean productivity rate of $120 \mathrm{~g} \mathrm{CaCO}_{3} \mathrm{~m}^{-2} \mathrm{yr}^{-1}$ was used to estimate the contribution of foraminifera to the carbonate produced in each quadrat where they were recorded, a figure which lies mid-way between Langer et al.'s (1997) low- and highproductivity environment estimates. Langer et al.'s (1997) mean rates for these two types of environment, 30 and $230 \mathrm{~g} \mathrm{~m}^{-2} \mathrm{yr}^{-1}$, were used as minimum and maximum estimates. For each quadrat the best-estimate $120 \mathrm{~g} \mathrm{~m}^{-2} \mathrm{yr}^{-1}$ figure (as well as the 30 and $230 \mathrm{~g} \mathrm{~m}^{-2} \mathrm{yr}^{-1}$ minimum and maximum figures) was multiplied by a factor of between 0 and 3 depending on the density of live foraminifera counted during the ecological census.

\section{Molluscs}

Although their shells of ten comprise a significant proportion of sediments, most reef carbonate budgets omit mollusc production (eg. Stearn et al. 1977; Sadd 1984; Eakin 1996; Vecsei 2001) and, as a result, there is a paucity of literature on their calcification. When mollusc production is included, it is of ten estimated using the abund ance of shells in sediment deposits (eg. Hubbard et al. 1990; Yamano et al. 2000). However, the age of such sediments is highly variable (Roy 1991; Harney et al. 2000) and often spans the period of recent high sea levels, which exceeds 2000 years in Torres Strait (Woodroffe et al. 2000). Further, the shells of dead molluscs in any one area (eg. a quadrat) are a poor indicator of immediate live assemblages due to the influence of taphonomic processes, such as post-mortem transport and deposition out of production areas (Cummins et al. 1986a-b; Zuschin et al. 2000).

Table A5 Published es timates of shell production rates meas ured from living mollusc assemblages a estimated annual shell production rates calculated from the soft tiss ue to total weigh ratios and soft-tis sue and total production figures given in the original

\begin{tabular}{lcc}
\hline \multicolumn{1}{c}{ Type and/or Species } & $\begin{array}{c}\text { Calcific ation } \\
\left(\mathrm{g} \mathrm{CaCO}_{3} \mathrm{~m}^{-2} \mathrm{yr}^{-1}\right)\end{array}$ & Source \\
\hline micromolluscs - on hard substrates & $9-180$ & Harney \& Fle tcher 2003 \\
micromolluscs - in Halimeda beds & $210-540$ & Harney \& Fletcher 2003 \\
micromolluscs - average & 70 & Harney \& Fle tcher 2003 \\
macromollusc - T. maxima & 4.8 & Richard 1981 \\
macromollusc - C. fragum & 0.22 & ${\text { Richard } 1981^{\mathrm{a}}}^{\mathrm{a}}$
\end{tabular}

In the present study, a rate $100 \mathrm{~g} \mathrm{CaCO}_{3} \mathrm{~m}^{-2} \mathrm{yr}^{-1}$ is used to indicate mollusc production. This rate lies between the few published rates for micro- and macromolluscs (Table A5). Comparisons between field observations of the volume of molluscs found in individual quadrats, and the weight of an equivalent 
volume of empty shells (which require no correction for organic content, Harney et al. 2000), indicates that this estimate is realistic. Minimum and maximum estimates of 10-200 $\mathrm{g} \mathrm{CaCO}_{3} \mathrm{~m}^{-2} \mathrm{yr}^{-1}$ are used to test the sensitivity of total carbonate production figures to variation in mollusc production rates. For each quadrat the best-estimate $100 \mathrm{~g} \mathrm{~m}^{-2} \mathrm{yr}^{-1}$ figure (as well as the 10 and $200 \mathrm{~g} \mathrm{~m}^{-2} \mathrm{yr}^{-1}$ minimum and maximum figures) was multiplied by a factor of between 0 and 3 depending on the density of live molluscs counted during the ecological census.

\section{References}

Adey WH, Vassar JM (1975) Colonization, succession and growth rates of tropical crustose coralline algae (Rhodophyta, Cryptonemiales). Phycologia 14:55-69

Bottjer DJ (1980) Branching morphology of the reef coral Acropora cervicornis in different hydraulic regimes. J Paleon tol 54:1102-1107

Buddemeier RW, Smith SV, Kinzie RA (1975) Holocene windward reef-flat history, Enewetak Atoll. Geol Soc Am Bull 86:1581-1584

Charuchinda M, Chansang H(1985) Skeleton extension and banding formation of Porites lutea of fringing reefs along the south and west coasts of Phuket Island (Thailand). Proc 5th Int Coral Reef Symp 6:83-87

Charuchinda M, Hylleberg J (1984) Skeletal extension of Acropora formosa at a fringing reef in the Andaman Sea. Coral Reefs 3:215-219

Crossland CJ (1981) Seasonal growth of Acropora cf. formosa and Pocillopora damicornis on a high latitude reef (Houtman Abrolhos, Western Australia). Proc 4th Int Coral Reef Symp 1:663-667

Cummins H, Powell EN, Stanton RJ Jr., Staff G (1986a) The rate of taphonomic loss in modern benthic habitats: how much of the potentially preservable community is preserved? Palaeogeogr Palaeoclimatol Palaeoecol 52:291-230

Cummins H, Powell EN, Stanton RJ Jr., Staff G (1986b) The size frequency distribution in palaeoecology: effects of the taphonomic process during formation of molluscan death assemblages in Texas Bays. Palaeontology (Oxford) 29:495-518

Drew EA (1983) Halimeda biomass, growth rates and sediment generation on reefs in the Great Barrier Reef Province. Coral Reefs 2:101-110

Drew EA, Abel KM (1985) Biology, sedimentology and geo graphy of the vast inter-reefal Halimeda meadows within the Great Barrier Reef Province. Proc 5th Int Coral Reef Symp 5:15-20

Eakin CM (1992) Post-El Niño Panamanian reefs: less accretion, more erosion and damselfish protection. Proc 7th Int Coral Reef Symp 387-396

Eakin CM (1996) Where have all the carbonates gone? A model comparison of calcium carbonate budgets before and after the 1982-1983 El Niño at Uva Island in the eastern Pacific. Coral Reefs 15:109-119

Freile D, Milliman JD, Hillis L (1995) Leeward bank margin Halimeda meadows and draperies and their sedimentary importance on the western Great Bahama Bank slope. Coral Reefs 14:27-33

Glynn PW (1976) Some physical and biological determinants of coral community structure in the eastern Pacific. Ecol Monogr 46:431-456

Glynn PW, Stewart RH (1973) Distribution of coral reefs in the Pearl Islands (Gulf of Panama) in relation to thermal conditions. Limnol Oceanogr 18:367379 
Glynn PW, Veron JEN, Wellington GM (1996) Clipperton Atoll (eastern Pacific): oceanography, geomorphology, reef-building coral ecology and biogeography. Coral Reefs 15:71-99

Graus RG, Chamberlain JA, Boker AM (1977) Structural modification of corals in relation to waves and currents. In: Frost SH, Weis s MP, Saunders JB (eds) Reefs and Related Carbonates - Ecology and Sedimentology, American Society of Petroleum Geologists, Studies in Geology 4:135-153

Grigg RW (1982) Darwin point: a threshold for atoll formation? Coral Reefs 1:2934

Guzman HM, Cortes J (1989) Growth rates of eight species of scleractinian corals in the eastern Pacific (Costa Rica). Bull Mar Sci 44:1186-1194

Hallock P (1981) Production of carbonate sediments by selected large benthic foraminifera on two Pacif ic coral reefs. J Sediment Petrol 51:467-474

Hallock P, Cottey TL, Forward LB, Halas J (1986) Population biology and sediment production of Archaias angulatus (Foraminiferida) in Largo Sound, Florida. J Foraminifer Res 16:1-8

Harney JN, Fletcher CH (2003) A budget of carbonate framework and sediment production, Kailua Bay, Oahu, Hawaii. J Sediment Res 73:856-868

Harney JN, Grossman EE, Richmond BM, Fletcher CH (2000) Age and composition of carbonate shoreface sediments, Kailua Bay, Oahu, Hawaii. Coral Reefs 19:141-154

Harriott VJ (1998) Growth of the staghorn coral Acropora formosa at Houtman Abrolhos, Western Australia. Mar Biol 132:319-325

Highsmith R (1979) Coral growth rates and environmental control of density banding. J Exp Mar Biol Ecol 37:105-125

Hillis-Colinvaux L (1974) Productivity of the coral reef alga Halimeda (order Siphonales). Proc 2nd Int Coral Reef Symp 1:35-42

Hubbard DK Miller AI, Scaturo D (1990) Production and cycling of calcium carbonate in shelf-edge reef systems (St Croix, U.S. Virgin Islands): Applications to the nature of reef systems in the fossil record. J Sediment Petrol 60:335-360

Hudson JH (1985) Growth rate and carbonate production in Halimeda opuntia: Marquesas Keys, Florida. In: Toomey DF, Nitecki MH (eds) Paleoalgology: contemporary research and applications. Springer-Verlag, Berlin, pp 257-263

Hughes T P (1987) Skeletal density and growth form of corals. Mar Ecol Prog Ser 35:259-266

Hughes TP, Jackson JBC (1985) Population dynamics and life histories of foliaceous corals. Ecol Monogr 55:141-166

Huston M (1985) Variation in coral growth rates with depth at Discovery Bay, Jamaica. Coral Reefs 4:19-25

Klein R, Patzold J, Wefer G, Loya Y (1993) Depth-related timing of density band formation in Porites spp. Corals from the Red Sea inferred from X-ray chronology and stable isotope composition. Mar Ecol Prog Ser 97:99-104

Knutson D, Buddemeier R, Smith S (1972) Coral chronometers: seasonal growth bands in coral reefs. Science 177:270-272

Langer MR, Silk MT, Lipps JH (1997) Global ocean carbonate and carbon dioxide production: The role of reef foraminifera. J Foraminifer Res 27:271277

Marsh LM (1993) The occurrence and growth of Acropora in extra-tropical waters off Perth, Western Australia. Proc 7th Int Coral Reef Symp 1233-1238 
Matsuda S (1989) Succession and growth rates of encrusting crusto se coralline algae (Rhodophyta, Cryptonemiales) in the upper fore-reef environment off Ishigaki Island, Ryukyu Islands. Coral Reefs 7:185-195

Muller PH (1974) Sediment production and population biology of the benthic foraminifer Amphistegina madagascariensis. Limnol Oceanogr 19:802-809

Muller PH (1976) Sediment production by shallow-water, benthic foraminifera at selected sites on Oahu, Hawaii. Maritime Sediments Special Publication 1:263265

Multer HG (1988) Growth rate, ultrastructure and sediment contribution of Halimeda incrassata and Halimeda monile, Nonsuch and Falmouth Bays, Antigua, W.I. Coral Reefs 6:179-186

Neudecker S (1977) Transplant experiments to test the effect of fish grazing on coral distribution. Proc 3rd Int Coral Reef Symp 1:317-323

Oliver JK, Chalker BE, Dunlap WC (1983) Bathymetric adaptations of reefbuilding corals at Davies Reef, Great Barrier Reef, Australia. I. Long-term growth responses of Acropora formosa (Dana 1846). J Exp Mar Biol Ecol 73:11-35

Payri CE (1988) Halimeda contribution to organic and inorganic production in a Tahitian reef system. Coral Reefs 6:251-262

Richard G (1981) A first evaluation of the findings on the growth and production of lagoon and reef molluscs in French Polynesia. Proc 4th Int Coral Reef Symp 2:637-641

Roy PS (1991) Shell hash dating and mixing models for palimpsest marine sediments. Radiocarbon 33:283-289

Sadd JL (1984) Sediment transport and $\mathrm{CaCO}_{3}$ budget on a fringing reef, Cane Bay, St Croix, U.S. Virgin Islands. Bull Mar Sci 35(2):221-238

Sakai K, Nishihira M (1981) Population study of the benthic foraminifer Baculogypsina sphaerulata on the Okinawan Reef flat and preliminary estimation of its annual production. Proc 4th Int Coral Reef Symp 2:763-766

Schuhmacher H, Plewka M (1981) The adaptive significance of mechanical properties versus morphological adjustments in skeletons of Acropora palmata and Acropora cervicornis (Cnidaria, Scleractinia). Proc 4th Int Coral Reef Symp 2:121-128

Scoffin TP, Tudhope AW, Brown BE, Chandang H, Cheen ey RF (1992) Patterns and possible environmental controls of skeletogenesis of Porites lutea, South Thailand. Coral Reefs 11:1-11

Stearn CW, Scoffin TP, Martindale W (1977) Calcium carbonate budget of a fringing reef on the west coast of Barbados. Bull Mar Sci 27:479-510

Stimson J (1996) Wave-like outward growth of some table- and plate-forming corals and a hypothetical mechanism. Bull Mar Sci 58:301-313

Tudhope AW, Scoffin TP (1988) The relative importance of benthic foraminiferas in the production of carbonate sediment on the Central Queensland Shelf. Proc 6th Int Coral Reef Symp 2:583-588

Vecsei A (2001) Fore-reef carbonate production: development of a regional census-based method and first estimates. Palaeogeogr Palaeoclimatol Palaeoecol 175:185-200

Wefer G (1980) Carbonate production by algae Halimeda, Penicillus and Padina. Nature 285:323-324

Wellington GM (1982) Depth zonation of corals in the Gulf of Panama: control and facilitation by reef fishes. Ecol Monogr 52:223-241 
Wellington GM, Glynn PW (1983) Environmental influences on skeletal banding in eastern Pacific (Panama) corals. Coral Reefs 1:215-222

Woodroffe CD, Kennedy DM, Hopley D, Rasmussen CE, Smithers SG (2000)

Holocene reef growth in Torres Strait. Mar Geol 170:331-346

Yamano H, Miyajima T, Koike I (2000) Importance of foraminifera for the formation and maintenance of a coral sand cay: Green Island, the Great Barrier Reef, Australia. Coral Reefs 19:51-58

Yap HT, Gomez ED (1984) Growth of Acropora pulchra. II. Respon ses of natural and transplanted colonies to temperature and day length. Mar Biol 81:209-215

Zuschin M, Hohenegger J, Steininger FF (2000) A comparison of living and dead molluscs on coral reef associated hard substrata in the northern Red Sea implications for the fossil record. Palaeogeogr Palaeoclimatol Palaeoecol 159:167-190 